\title{
Antidepressants in the treatment of depression/depressive symptoms in cancer patients: a systematic review and meta-analysis
}

Zacharias G Laoutidis ${ }^{1,2^{*}}$ and Klaus Mathiak ${ }^{1,3,4}$

\begin{abstract}
Background: Over the past thirty years a number of studies have suggested that antidepressants can be effective in the treatment of depressive symptoms in patients with cancer. The aim of this paper was to review randomized controlled trials (RCTs) and to perform a meta-analysis in order to quantify their overall effect.

Methods: Pubmed and the Cochrane libraries were searched for the time period between 1980 and 2010.

Results: Nine RCTs were identified and reviewed. Six of them (with a total of 563 patients) fulfilled the criteria for meta-analysis, but exhibited an unclear risk for bias. The estimated effect size was 1.56 with $95 \%$ Cl: 1.07- 2.28 $(p=0.021)$. There were no differences in discontinuation rates between antidepressants and placebo groups $(\mathrm{RR}=0.86$ with $95 \% \mathrm{Cl} 0.47-1.56, \mathrm{p}=0.62$ ).

Conclusions: This meta-analysis suggests that antidepressants can be effective in treating depressive symptoms beside clinical depression. When considering the risk of side effects and interactions and the heterogeneity among the mostly small studies, a general recommendation cannot be made until well-controlled studies are conducted.
\end{abstract}

Keywords: Depression, Depressive symptoms, Cancer, Antidepressants

\section{Background}

The role of depression in physical illness has been recognized and addressed by many authors. Up to one third of physically ill patients attending hospital have depressive symptoms. The diseases with the highest prevalence of major depression have been reported as follows (from higher to lower incidence): inflammatory bowel disease, multiple sclerosis, epilepsy, asthma, back problems, cancer, COPD, migraine, rheumatic arthritis, stroke, Parkinson's disease, diabetes mellitus, and heart disease [1]. Over the last several years, there has been a growing interest for the psychological aspects of cancer due to its severe impact on quality of life (QOL) [2,3]. Physical symptoms that are associated with both depression and cancer can be a confounding factor in the assessment of depression in this population [4]. Several studies evaluated the efficacy of

\footnotetext{
* Correspondence: Zacharias.Laoutidis@lvr.de

'Department of Psychiatry, Psychotherapy and Psychosomatics, RWTH University of Aachen, Bergische Landstrasse 2, 40629 Düsseldorf, Germany ${ }^{2}$ Department of Psychiatry, University of Düsseldorf, Bergische Landstrasse 2, 40629 Düsseldorf, Germany

Full list of author information is available at the end of the article
}

psychological and pharmacological interventions in the treatment of depression. The psychopharmacological interventions and particularly the use of antidepressants are systematically reviewed here and meta-analytical methods are applied to quantify their overall effect.

Cancer is associated with depression and depressive symptoms. A meta-analysis by Mitchel et al. [5] included 94 studies and found that the pooled prevalence of major depression in palliative care settings and haematooncological settings was equal to $16.5 \%$ (95\% CI: 13.1 $20.3 \%$ ) and $16.3 \%$ (95\% CI: 13.4-19.5\%), respectively. Restricting the analysis to standardized clinical assessment, $\mathrm{Ng}$ and colleagues [6] found a prevalence of $10.8 \%$ and also a substantial amount of heterogeneity. Even though these rates appear to be high, a consistent difference to a systematically matched sample from general population data is still controversial. The existing data suggest that "survivorship presents ongoing psychological challenges" [7].

There are two main confounding factors in the assessment of depression in cancer patients. First, the distinction 
between normal sadness or grief and symptoms indicating a depressive episode is not well-defined. Indeed, a phase of reduced mood or depression is considered part of healthy coping with grief (e.g. Kübler-Ross already in 1969 [8]). Further, such reaction patterns may recur as the disease progresses, by treatment failure, or by findings of metastases. Therefore, also time criteria may not capture the dynamics of disease progression.

A second confounder is the lack of specificity of the depressive symptoms. The ICD-10 and DSM-IV criteria for depressive episode include symptoms that are often present in patients with cancer as well, e.g. loss of appetite, low energy levels, or sleep disturbance. Therefore, the definition of depression in cancer patients and in physical illness is ambiguous [4]. It is suggested to identify the patients by their symptoms and not by a clinical syndrome because the ability to detect cases of depressive episode or disorder may be less important than the ability to detect depressive symptoms remediable to treatment [9]. Several approaches have been developed to solve the problem of diagnosing depression in cancer patients [10]. For instance, the substitutive approach suggests that all physical/somatic symptoms (change in appetite/weight, sleep disturbance, fatigue, loss of energy, diminished ability to think or concentrate) are replaced by non-somatic symptoms (tearfulness, depressed appearance, social withdrawal, decreased talkativeness, brooding, self-pity, pessimism, lack of reactivity, blunting) [11]. These are known as the Endicott criteria. Therefore, established criteria for depression may not be better suited to detect therapeutic indications in cancer patients than the presence of depressive symptoms.

Many guidelines for the treatment of cancer recommend that all cancer patients should be screened for depression, pain, and fatigue (e.g. by the National Institute of Health [12]). Multi-item scales are used for screening and diagnosing depression. Quantified results are used to specify the illness severity and to monitor the course of the disease. For detecting depression, ultra brief screening tools have been developed and proven to be reliable. For instance, Chochinov reported that the single question: "Are you depressed?" can be a reliable screening tool [13]. There is clear evidence that the systematic application of screening instruments reduces false negative findings, but the specificity and effects on outcome measures not sufficiently studied [14].

Depression seems to influence the prognosis and even the survival of cancer patients. For instance, Satin et al. conducted a meta-analysis with 27 studies on mortality in cancer patients and depression. A significant effect of depression on mortality was reported (RR: $1.25, \mathrm{P}<0.001$ ). The majority of studies measured the effect of depressive symptoms and only three of them included patients with clinical depression. A correlation with disease severity cannot be excluded [15]. In a large cohort study, patients who had recently received a cancer diagnosis had an increased risk for both suicide and death from cardiovascular causes as compared with controls [16]. Trials found that a decrease in severity of depressive symptoms is associated with a prolongation of survival in cancer patients $[17,18]$. However, these findings remain controversial as the majority of studies failed to replicate them [19-22].

\section{Treatment of depression in patients with cancer}

The treatment of depression can mainly be divided into two categories: psychosocial and pharmacological interventions. A meta-analysis found that cognitive behavioral therapy has a positive effect on depression and quality of life in patients with cancer. In the same meta-analysis patient education had a positive influence on quality of life but not on depression [23]. A further meta-analysis of psychotherapeutic and psychopharmacological studies found allover positive effects on depression ratings [24]. Metaanalyses focusing on pharmacological treatment give a less consistent picture.

Previous reviews [6,25-28] underpinned the lack of evidence of the adequate effect of pharmacological interventions in the treatment of depression in cancer patients. However, the reviewed studies were heterogeneous as concerns the studied population (e.g. fatigue or pain as eligibility criterion and depression as secondary outcome) and the type of the drug applied (e.g. antidepressants, benzodiazepines, antipsychotics, psychostimulants, etc.). Only limited conclusions could be drawn from these reviews for the effectiveness of antidepressants in this population. A metaanalysis estimated the efficacy of antidepressants in palliative care (patients with cancer, HIV, COPD, etc.; [29]). The overall effect of antidepressants was significantly higher than the effect of placebo. However, only four of the twenty-five studies included cancer patients. A subgroup analysis was not performed for each subpopulation and thus no recommendation can be given for oncological patients. In another meta-analysis, antidepressants were found to be effective in the treatment of major depression with a co-morbid physical illness $(\mathrm{RR}=1.42, \mathrm{P}<0.0001)$. Again, only four RCTs were included that studied cancer patients with a diagnosis of major depression and no significant effect of antidepressants on response rates emerged in this subpopulation $(\mathrm{R} R=1.26, \mathrm{P}=0.19)$ [30]. In contrast, Hart et al. [24] found a significant effect on depression ratings in the subgroup of four pharmacological studies which was not significantly different from the overall effect of the psychotherapeutic trials. However, this analysis included one placebo group twice and used Hedge's g to quantify the results, which may bias statistics in the pharmacological subgroup. The authors discuss as a limitation that changes in questionnaire ratings may have limited clinical relevance. Depressiveness even without manifest diagnosis of depression may have adverse effects on prognosis and quality of 
life in cancer patients (see [14]) and, therefore, these patients should be included in intervention trials and subsequent meta-analyses. To overcome the limitations of the previous analyses, the present systematic review and metaanalysis focuses on the event of clinical relevant symptom changes in depressed or depressive patients with cancer.

\section{Methods}

\section{Search strategy}

The aim of the present study was to determine whether antidepressants are effective in the treatment of depression and depressive symptoms in patients with cancer. The inclusion criteria for the studies were:

1. Double-blind randomized-controlled trials (RCTs), which could be placebo-controlled or head-to-head trials. For the purposes of the meta-analysis only placebo-controlled trials were used.

2. The eligibility criteria of the studies were the presence of depression or depressive symptoms in patients with malignancy, i.e. impaired mood had to be diagnosed by clinical criteria or relevant depression rating scales.

3. The primary outcome of the studies was reduction in severity of depression or depressive symptoms.

4. The studies were published in English in the time between 01.01.1980 and 31.12.2010.

Antidepressants are often used for indications other than depression (e.g. fatigue, pain, hot flashes) in patients with malignancy. Thus, we excluded all studies, which had depression as a secondary outcome only.

We searched for studies in the electronic databases Pubmed and the Cochrane Library. We aimed towards higher sensitivity and lower precision in this first selection in order not to miss an appropriate study. In particular, we omitted any search term for therapy or treatment, which could reduce the search sensitivity. This approach is suggested by the "Cochrane Handbook for systematic Reviews of Interventions" (\$6.4.4) [31]. Search terms were: “(depressive OR depression) AND (cancer OR tumor OR neoplasm OR lymphoma OR leukemia)". The applied limits of the search were 1 . articles should be published in the time between 01.01.1980 and 31.12.2010; 2. articles should be in English language; and 3. the search term appeared in the title or the abstract of the articles. We further searched through the reference lists of reviews and relative articles to identify any additional studies. Exploratory extensions of search terms (e.g. including 'oncology') did not yield additional studies.

\section{Article selection and review strategy}

The selection of studies involved an initial screening of the title and the abstract in order to find studies, which were appropriate according to the inclusion criteria stated above. If it was not clear from the title or the abstract that the study should be rejected, the full text was obtained. The process was conducted independently by both authors in order to reduce the possibility of relevant articles being rejected.

The data were extracted independently by both authors. In case of disagreement, a clinician experienced in psychooncology and liaison psychiatry could be involved to mediate consensual decisions. A structured format was used as the one applied in the presentation of the single studies in the appendix. Dichotomous data were collected for the primary outcomes of this review (responders and nonresponders to treatment). Secondary outcomes were the number of drop outs, the number of patients with adverse effects, and the quality of life.

\section{Statistical methods (meta-analysis)}

A random effects model was applied in the metaanalysis because of the assumption that the true effect size was not the same in all studies. Indeed, there were marked differences between the studies regarding the type of cancer, the stage of cancer, the drug used in each study, and the design (intention to treat analysis or completers' analysis). The risk ratio (RR with 95\% confidence intervals) was preferred to odds ratio for the computation of the effect size because it has the advantage of being more intuitive [32]. Heterogeneity $\mathrm{I}^{2}$ was computed in order to assess the percentage of the overall variability attributed to the between studies variability.

The risk of bias in individual studies was evaluated using the Cochrane Collaboration's domain based tool which assesses allocation concealment, sequence generation, blinding, selective outcome reporting, and other sources of bias. Risk of publication bias was assessed using a funnel plot, i.e. a display of estimated study quality in terms of standard error and the reported effect size. The calculations were performed using standard formulas [32] in MicroSoft Excel (Excel 2003 Edition, MicroSoft, Redmond, CA). The statistical program "Comprehensive meta-Analysis" ( $2^{\text {nd }}$ version, Biostat, Englewood, NJ) was used to create forest and funnel plots.

\section{Results}

\section{Search results}

The electronic searches yielded 5959 references from MEDLINE and 1041 references (clinical trials) from the Cochrane Library. After the initial scanning of the abstracts, a total of 38 reports were detected that may relate to drug trials using anti-depressants. Based on the full-text of these reports, 29 of them were rejected since they did not reported RCTs on anti-depressant treatment in depressive cancer patients Figure 1. From the remaining 9 RCTs, 3 studies were head-to-head trials, 


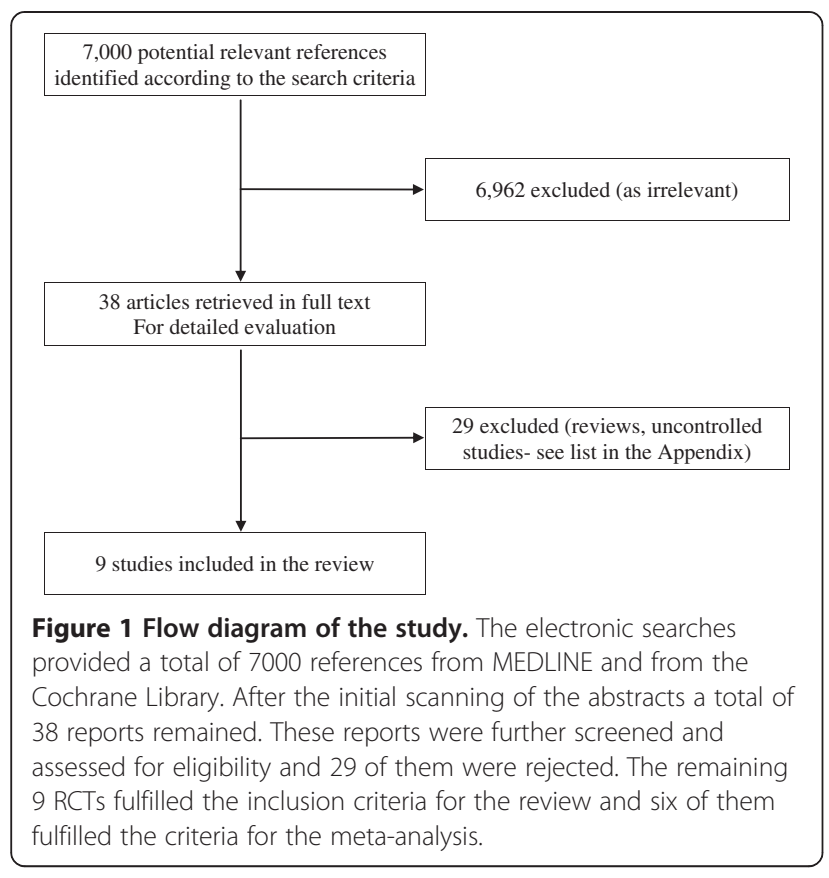

i.e. active drugs were compared with each other [33-35]. Thus in total 6 randomized placebo-controlled studies fulfilled the criteria for this meta-analysis [36-41]. Table 1 provides an overview of the reviewed studies. The complete list of the assessed trials is presented in Appendix A.

Previous reviews and meta-analyses exhibited a larger diversity of study designs [25-28]. For instance, we did not include 3 trials that had not depression or depressive symptoms as an eligibility criterion even though the primary outcome measure was improvement in depression/ depressive symptoms [42-44]. Similarly, we did not include trials which tested the efficacy of antidepressants in preventing depressive symptoms in patients with cancer [45] or in patients with melanoma undergoing therapy with interferon [46]. Appendix D lists all the 38 trials, which were screened and the reasons for in- or excluding them.

\section{Review of RCTs in depression}

A. Head-to-head trials

Holland et al. [33] studied 38 patients with depression and breast cancer. The selective serotonine reuptake inhibitor (SSRI) fluoxetine was not found to be superior to the tricyclic antidepressant (TCA) desipramine. Similarly, Pezella et al. [34] found no significant differences in efficacy between paroxetine (SSRI) und amitryptiline (TCA) in a sample of 185 patients with breast cancer. In contrast, the noradrenergic and specific serotonergic antidepressant (NaSSA) mirtazapine had a larger effect on depression than imipramine in a sample of 53 cancer patients with depression (Cancurtaran et al. 2008; [35]).

B. Placebo-controlled studies

Costa et al. [36] and van Heeringen et al. [37] compared the tetracyclic antidepressant mianserin with placebo in 73 and 55 patients with gynecological tumors, respectively. Both publications reported a significant effect on the observed depressive symptoms. In contrast, a trial by Razavi et al. [38] in 91 patients with various types of cancer did not reveal a significant difference between fluoxetine and placebo. Similarly, Fisch et al. [39] failed to demonstrate an advantage of fluoxetine over placebo in a sample of 163 patients with advanced cancer. A reevaluation of the results of the former study with the generalized estimating equation (GEE) method of regression suggested a significant effect of the verum as well. Navari et al. [40] found a significant effect of fluoxetine in 193 depressive patients with breast cancer. Finally, Musselmann et al. [41] could not document a drug effect in a trial with a small number of patients $(n=35)$ and 3 groups (paroxetine, desipramine, placebo). For the purposes of the current metaanalysis, we created a combined intervention group, which included the patients from both the paroxetine and the desipramine group, as recommended in the Cochrane handbook [31].

\section{Meta-analysis}

\section{Effect size}

All studies defined a measure of response, i.e. what was considered a meaningful improvement of the depressive symptoms. The overall effect size in the analysis is $\mathrm{RR}=1.56$ with $95 \%$-CI: $1.07-2.28$ ( $\mathrm{p}=0.021$ ), i.e. under the antidepressants a therapeutic response (as defined in the considered studies) is about 50\% more likely than in the placebo group (see Table 2). A graphical display of the relative strength of each study is presented in the forest plot (Figure 2). Four studies found a positive effect of the antidepressants on depressed cancer patients. In the other two studies no significant difference emerged but the $95 \%$ confidence intervals were wider than those of the four other studies (Figure 1). This can be considered as indicative of low precision in the trials with negative finding.

\section{Heterogeneity}

The meta-analysis revealed a substantial heterogeneity $\mathrm{I}^{2}=71 \%$ with $95 \%$ CI: $54 \%-82 \%$. For a substantial $\mathrm{I}^{2}$ (50-90\%), the "Cochrane Handbook for systematic Reviews of Interventions" [31] recommends a reanalysis without the outlying studies as part of a sensitivity analysis. Indeed, the RR of the study by Navari et al. [40] is 
Table 1 Overview of the reviewed studies

\begin{tabular}{|c|c|c|c|c|c|c|c|c|}
\hline Author & Year & Drug & Study design & Participants (n) & Duration & $\begin{array}{l}\text { Type of } \\
\text { cancer/Stages }\end{array}$ & Evaluation & Results \\
\hline \multicolumn{9}{|c|}{ A. Head-to-head trials } \\
\hline Holland & 1998 & $\begin{array}{l}\text { Fluoxetine vs. } \\
\text { Desipramine }\end{array}$ & $\begin{array}{l}\text { Double blind RCT, } \\
\text { ITT analysis, LOCF } \\
\text { approach }\end{array}$ & $\mathrm{n}=38$ & 6 weeks & $\begin{array}{l}\text { Breast cancer, } \\
\text { Stages II, III, IV }\end{array}$ & $\begin{array}{l}\text { HDRS Other: } \\
\text { CGI, PGI, HAS, } \\
\text { FLIC, MPAC, } \\
\text { SF-36 HS }\end{array}$ & $\begin{array}{l}\text { No significant difference } \\
\text { between fluoxetine and } \\
\text { desipramine. }\end{array}$ \\
\hline Pezella & 2001 & $\begin{array}{l}\text { Paroxetine vs. } \\
\text { Amitriptyline }\end{array}$ & $\begin{array}{l}\text { Double blind RCT, } \\
\text { ITT analysis, LOCF } \\
\text { approach }\end{array}$ & $\begin{array}{l}\mathrm{n}=179177 \\
\text { received } \\
\text { medication }\end{array}$ & 8 weeks & $\begin{array}{l}\text { Breast cancer, } \\
\text { any stage }\end{array}$ & $\begin{array}{l}\text { MADRS Other: } \\
\text { CGI, FLIC, PGE }\end{array}$ & $\begin{array}{l}38 / 88 \text { subjects in the } \\
\text { drug group and } 33 / 87 \text { in } \\
\text { the amitryptiline group } \\
\text { were responders } \\
(p=0.441)\end{array}$ \\
\hline Cancurtaran & 2008 & $\begin{array}{l}\text { Mirtazapine vs. } \\
\text { Imipramine vs. } \\
\text { Control } \\
\text { groupwithout } \\
\text { medication }\end{array}$ & $\begin{array}{l}\text { Double blind (for } \\
\text { the participants of } \\
\text { the two drug } \\
\text { groups) RCT, } \\
\text { completers' } \\
\text { analysis }\end{array}$ & $\mathrm{n}=53$ & 6 weeks & NR & SCID, HADS & $\begin{array}{l}\text { Significant improvement } \\
\text { in the mirtazapine group } \\
\text { No significant change in } \\
\text { the other two groups. }\end{array}$ \\
\hline \multicolumn{9}{|c|}{ B. Placebo controlled studies } \\
\hline Costa & 1985 & Mianserin & $\begin{array}{l}\text { Double blind RCT, } \\
\text { ITT analysis, LOCF } \\
\text { approach }\end{array}$ & $n=73$ & 4 weeks & $\begin{array}{l}\text { Gynecological } \\
\text { cancer, stages } \\
\text { II, III, IV }\end{array}$ & $\begin{array}{l}\text { ZSDRS, HDRS, } \\
\text { CGI-S }\end{array}$ & $\begin{array}{l}28 / 36 \text { in the Mianserin } \\
\text { group and } 18 / 37 \text { in the } \\
\text { placebo group were } \\
\text { responders }(p<0.025) \text {. }\end{array}$ \\
\hline Van Heeringen & 1996 & Mianserin & $\begin{array}{l}\text { Double blind RCT, } \\
\text { ITT analysis, LOCF } \\
\text { approach }\end{array}$ & $\mathrm{n}=55$ & 7 weeks & $\begin{array}{l}\text { Breast cancer, } \\
\text { stages I, II }\end{array}$ & HDRS & $\begin{array}{l}19 / 28 \text { patients in the } \\
\text { mianserin group and } \\
10 / 27 \text { in the placebo } \\
\text { group were responders } \\
(p=0.044) \text {. }\end{array}$ \\
\hline Razavi & 1996 & Fluoxetine & $\begin{array}{l}\text { Double blind RCT, } \\
\text { completers' } \\
\text { analysis }\end{array}$ & $n=91$ & 5 weeks & $\begin{array}{l}\text { Any kind of } \\
\text { cancer, any } \\
\text { stage }\end{array}$ & $\begin{array}{l}\text { HADS Other: } \\
\text { MADRS, HAS, } \\
\text { SCL-90R, SQOLI }\end{array}$ & $\begin{array}{l}18 \% \text { in the fluoxetine } \\
\text { group and } 20 \% \text { in the } \\
\text { placebo group were } \\
\text { responders (no significant } \\
\text { difference) }\end{array}$ \\
\hline Fisch & 2003 & Fluoxetine & $\begin{array}{l}\text { Double blind RCT, } \\
\text { Completers' } \\
\text { analysis }\end{array}$ & $n=163$ & 12 weeks & $\begin{array}{l}\text { Any type of } \\
\text { cancer, advanced } \\
\text { stage }\end{array}$ & $\begin{array}{l}\text { TQSS, FACT-G, } \\
\text { BZRDS }\end{array}$ & $\begin{array}{l}\text { Results available for } 129 \\
\text { patients. } 31 / 64 \text { patients } \\
\text { in the fluoxetine group } \\
\text { and } 23 / 65 \text { in the placebo } \\
\text { group were responders } \\
(\mathrm{p}=0.12) .\end{array}$ \\
\hline Musselmann & 2006 & $\begin{array}{l}\text { Paroxetine vs } \\
\text { Desipramine } \\
\text { vs placebo }\end{array}$ & $\begin{array}{l}\text { Double blind RCT, } \\
\text { ITT analysis, LOCF } \\
\text { approach }\end{array}$ & $\mathrm{n}=35$ & 6 weeks & $\begin{array}{l}\text { Breast cancer, } \\
\text { any stage }\end{array}$ & $\begin{array}{l}\text { DSM-III-R- } \\
\text { multiaxial } \\
\text { evaluation } \\
\text { HAD, HAS, CGI }\end{array}$ & $\begin{array}{l}5 / 13 \text { in the paroxetine } \\
\text { group, } 5 / 11 \text { in the } \\
\text { desipramine group and } \\
6 / 11 \text { in the placebo } \\
\text { group were responders } \\
\text { (no statistical significance). }\end{array}$ \\
\hline Navari & 2007 & Fluoxetine & $\begin{array}{l}\text { Double blind RCT, } \\
\text { completers' } \\
\text { analysis }\end{array}$ & $n=193$ & Six months & $\begin{array}{l}\text { Breast cancer, } \\
\text { stages I, II }\end{array}$ & $\begin{array}{l}\text { TQSS, BZDRS, } \\
\text { FACT-G }\end{array}$ & $\begin{array}{l}71 / 90 \text { subjects in the } \\
\text { fluoxetine group and } \\
23 / 90 \text { in the placebo } \\
\text { group showed a } \\
\text { significant }(p<0.01) \\
\text { improvement }(p<0.0005) \text {. }\end{array}$ \\
\hline
\end{tabular}

BZDRS: Brief Zung depression rating scale, CGI-S: Clinical global impression Scale for Severity of Illness, DSM: Diagnostic and statistical manual for mental disorders, FACT-G: Functional assessment of cancer therapy- global, FLIC: Functional living index- cancer, HAD: Hamilton Depression Scale, HADS: Hospital anxiety and depression scale, HAS: Hamilton anxiety scale, HDRS: Hamilton rating depression scale, ITT: Intention-to-treat, LOCF: last observation carried forward, MADRS: Montgomery and Asberg depression rating scale, MPAC: Memorial pain assessment card, NR: Not reported, PGE: Patients' global evaluation, PGI: Patients' global impression, RCT: Randomized controlled trial, SCID: Structured clinical interview for DSM, SF36-HS: Short Form 36 Health survey, SCL-90-R: Symptom Checklist 90, Revised, SQOLI: Spitzer Quality of Life Index, TQSS: Two questions screening survey, ZSRDS: Zung self-rating depression scale.

much higher than all other values (see Figure 2) and the analyses were repeated excluding this study. The effect of the antidepressants remained significantly better in comparison to placebo after excluding the outlying study $(\mathrm{RR}=1.39,95 \%-\mathrm{CI}: 1.09-1.77, \mathrm{p}=0.008)$ and the heterogeneity decreased to $10 \%$ (95\%-CI 0-22\%). Heterogeneity between $0 \%$ and $40 \%$ is considered to be of no importance [31]. This finding confirms that the high heterogeneity is most likely due to one outlier which however does not bias the finding. 
Table 2 Number of participants in both groups (drug and placebo) for each study

\begin{tabular}{|c|c|c|c|c|c|c|c|}
\hline \multirow[t]{2}{*}{ Author } & \multirow[t]{2}{*}{ Year } & \multirow[t]{2}{*}{ Verum } & \multicolumn{2}{|c|}{ Verum } & \multicolumn{2}{|c|}{ Placebo } & \multirow[t]{2}{*}{$\mathrm{RR}$} \\
\hline & & & Participants & Responders & Participants & Responders & \\
\hline Costa & 1985 & Mianserin & 36 & 28 & 37 & 18 & 1.60 \\
\hline Van Heeringen & 1996 & Mianserin & 28 & 19 & 27 & 10 & 1.83 \\
\hline Razavi & 1996 & Fluoxetine & 45 & 8 & 46 & 9 & 0.91 \\
\hline Fisch & 2003 & Fluoxetine & 64 & 31 & 65 & 23 & 1.37 \\
\hline Musselmann & 2006 & Paroxetine & 24 & 11 & 11 & 6 & 0.84 \\
\hline \multirow[t]{2}{*}{ Navari } & 2008 & Fluoxetine & 90 & 71 & 90 & 23 & 3.09 \\
\hline & & & 287 & 167 & 276 & 89 & \\
\hline
\end{tabular}

\section{Subgroup analysis}

Four factors differentiating the studies were identified post-hoc. The selected predictors were: 1. depression vs. depressive symptoms as eligibility criteria; 2 . analysis on an intention-to-treat (ITT) basis vs. completers' analysis; 3 . inclusion of all or only advanced cancer stages vs. inclusion of only early stages; and 4. the substance group SSRI vs. tetracyclic antidepressants (mianserin). In this post-hoc analysis, mianserin had significantly higher $R R$ for responders than the SSRIs $\left(\mathrm{RR}_{\mathrm{SSRI}}=1.16, \mathrm{RR}_{\text {mianserin }}=1.67\right.$, $\left.\mathrm{Z}_{\text {difference }}=-2.17, \mathrm{p}=0.03\right)$. In this latter subgroup comparison, only the paroxetine group from the study by Musselmann et al. was contrasted in order to make the intervention groups comparable. The other predictors did not significantly influence the RR for antidepressant effects. Appendix $\mathrm{C}$ provides the details of the subgroup analysis.

\section{Adverse effects and dropouts}

There was a substantial amount of missing data concerning the adverse effects in these studies. Only three studies reported the total number of patients with side effects. Four studies provided data about the number of drop outs because of side effects in each arm
(Table 3). Visual inspection suggested no difference. However due to missing data, we did not perform a meta-analysis for the adverse effects. All but one studies provided information about the number of dropouts in each arm (Table 4). We performed a meta-analysis using relative risk ratios and found no significant difference between dropouts in the verum and placebo groups (mean RR $=0.86,95 \%$-CI 0.47- 1.56, $\mathrm{p}=0.62$ ).

\section{Quality of life}

Only three of the six studies included an outcome measure for quality of life. Razavi et al. [38] used the Spitzer Quality of Life Index (SQOLI). The increase in the SQOLI scores was significant in both the drug and the placebo group, but the difference between the two groups was not statistically significant. Fisch et al. [39] used the Functional Assessment of Cancer TherapyGeneral (FACT-G, version 3). There was no significant difference between the fluoxetine and the placebo group in the proportion of responders (six points change). Using the generalized estimating equations (GEE) method of regression (post-hoc), there was a significant improvement in the total FACT-G scores in the fluoxetine group compared with placebo. Navari et al. [40] also

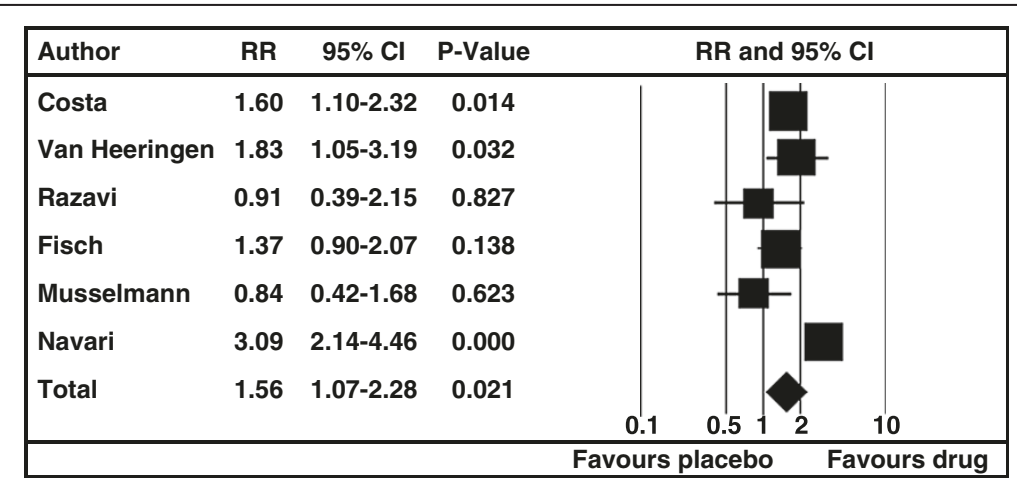

Figure 2 Forest plot of $\mathbf{R R}$ with $\mathrm{Cl}$ for all studies and overall. The overall effect size in the analysis is $\mathrm{RR}=1.56$ with $95 \%-\mathrm{Cl}: 1.07-2.28$ ( $p=0.021$ ). This means that the effect of antidepressants in this population is significant better than the placebo effect. Four studies found a positive effect of the antidepressants on depressed cancer patients. In two studies the antidepressant was not better than the placebo. The 95\%-Cls of these two studies were wider than the ones of the other four studies, which is indicative of low precision. RR: relative risk; Cl: confidence intervals. 
Table 3 Number of patients with adverse events

\begin{tabular}{|c|c|c|c|c|c|c|}
\hline \multirow[t]{2}{*}{ Author } & \multirow[t]{2}{*}{ Year } & \multirow[t]{2}{*}{ Drug } & \multicolumn{2}{|c|}{ Verum } & \multicolumn{2}{|c|}{ Placebo } \\
\hline & & & Participants & A.E. & Participants & A.E. \\
\hline Costa & 1985 & Mianserin & 36 & 17 & 37 & 11 \\
\hline Van Heeringen & 1996 & Mianserin & 28 & 11 & 27 & 17 \\
\hline Razavi & 1996 & Fluoxetine & 45 & 20 & 46 & 23 \\
\hline Fisch & 2003 & Fluoxetine & 64 & NR & 65 & NR \\
\hline Musselmann & 2006 & Paroxetine & 24 & $N R$ & 11 & $N R$ \\
\hline Navari & 2008 & Fluoxetine & 90 & $N R$ & 90 & $N R$ \\
\hline
\end{tabular}

A.E.: adverse event; NR: not reported.

used the FACT-G scale. The number of patients who had a significant improvement in quality of life was statistically significantly higher in the fluoxetine group as compared to the placebo group.

\section{Risk for bias and publication bias}

The risk of bias for each study can be determined by assessing the following six domains: 1 . sequence generation, 2. allocation concealment, 3. blinding, 4. missing data, 5 . selective outcome reporting, and 6 . other sources of bias [31]. The group of studies was relative homogenous and the overall risk for bias could be described as "unclear" (Figure 3). The results for every single trial are presented in the Appendix B. The risk for publication bias (i.e. studies with small sample size are more likely not to be published if their effect is small to moderate) is assessed by means of the funnel plot, which displays the relationship between the sample size and the effect size of the studies. The standard error instead of the sample size is usually used in the $\mathrm{Y}$ axis. No indication for publication bias can be derived from the present funnel plot; in particular, there was no gap on the bottom left side, which would be indicative of unpublished studies with small to moderate effects (Figure 4).

\section{Discussion}

This is the first systematic review with meta-analysis which focuses exclusively on the psychopharmacological treatment in cancer patients with depression. Treatment with SSRI or tetracyclic antidepressants was found to improve depressive symptoms more than placebo. The small number of studies and patients included, as well as the questionable risk of bias, however, points out the demand for well-conducted trials before general recommendations can be derived. The diagnosis and treatment of depression is of high importance in this population of patients because of the high risk for suicide [16], its impact on the quality of life [2,3], and its influence on anticancer treatment adherence and compliance [47]. Critical for an antidepressive treatment in this group of patients is a well-funded base of evidence since elevated risks of adverse effects and interactions must be expected (see adverse effects and side effects below). Interestingly in some cancer patients, subsyndromal depressive symptoms (with DSM-IV or ICD-10 diagnosis) may improve under the antidepressants as well. Direct comparisons between classical tricyclic antidepressants and SSRIs revealed no differences in two of the three reviewed head-to-head trials. The higher effect size of the tetracyclic agent mianserin in comparison to SSRIs as seen in the subgroup analysis - must therefore be considered exploratory. At this point no specific recommendation concerning effectiveness for a substance class can be made.

Several studies and meta-analyses have reported on the effectiveness of antidepressants in patients with depression and physical illness. Van der Feltz-Cornelis et al. [48] showed in a meta-analysis that pharmacological interventions are effective in reducing depressive

Table 4 Dropouts

\begin{tabular}{|c|c|c|c|c|c|c|}
\hline \multirow[t]{2}{*}{ Author } & \multirow[t]{2}{*}{ Year } & \multicolumn{2}{|c|}{ Verum } & \multicolumn{2}{|c|}{ Placebo } & \multirow[t]{2}{*}{ RR } \\
\hline & & Participants & Dropouts & Participants & Dropouts & \\
\hline$\overline{\text { Costa }}$ & 1985 & 36 & 7 & 37 & 15 & 0.48 \\
\hline Van Heeringen & 1996 & 28 & 6 & 27 & 15 & 0.39 \\
\hline Razavi & 1996 & 45 & 15 & 46 & 7 & 2.19 \\
\hline Fisch & 2003 & 83 & 19 & 80 & 15 & 1.22 \\
\hline \multirow[t]{2}{*}{ Musselmann } & 2006 & 24 & 10 & 11 & 5 & 0.92 \\
\hline & & 216 & 57 & 201 & 57 & 0.86 \\
\hline
\end{tabular}

RR: relative risk. 


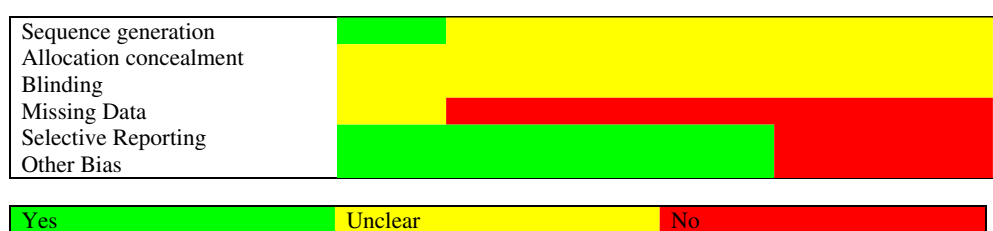

Figure 3 Risk of bias graph. The semaphore colors provide a visual impression of the quality of the study reports for meta-analysis; green: condition is fulfilled; yellow: condition is questionable and; red: condition is not fulfilled and risk of bias is present. The allover quality is unclear and indications for risk of bias can be derived. Therefore the meta-analysis cannot provide a high degree of level of evidence.

symptoms in patients with diabetes mellitus. Price et al. [49] found in another meta-analysis a significant effect of antidepressants in treating depression in patients with neurological disorders. There are RCTs which show a positive effect of SSRIs on depression in patients with asthma [50,51]. SSRIs were also found to be effective in the treatment of depression in patients with coronary artery disease [52]. Although the prevalence of depression in patients with inflammatory bowel disease (IBD) is high [1], there are no RCTs which assess the treatment of depression in this population [53].

\section{Depression and depressive symptoms}

There is a trend towards identifying depressive symptoms instead of trying to define exact diagnoses of concrete depressive syndromes $[9,10]$. There are also many simple single- or two-item screening tools, which can detect depression with high specificity and sensitivity. As shown in the subgroup analysis, patients with depressive symptoms can benefit from the use of antidepressants exactly like the patients diagnosed with major depression. On the one hand, this conclusion is of significant clinical importance because it addresses a practical issue and can motivate physicians to screen for depression with simple and easy to use tools. On the other hand, it must be taken into consideration that there was only one study in one of the two compared groups in the subgroup analysis [39]. The authors of this study reported a better response in the patients who had a score higher than 4 in the TQSS, suggesting that a minimum of symptom severity may be required for the antidepressive action of antidepressants. Thus, the results of the subgroup analysis should be interpreted very carefully and not be misinterpreted as an excuse for an unreasonable use of antidepressants by physicians or for the limitation of the role of the consultationliaison psychiatry in oncology.

\section{Side effects and interactions}

When using an antidepressant, one should pay attention on possible side effects such as pro-emetic effects of SSRIs and anticholinergic effects of TCA. Nausea is a common adverse effect among cancer patients undergoing chemotherapy and

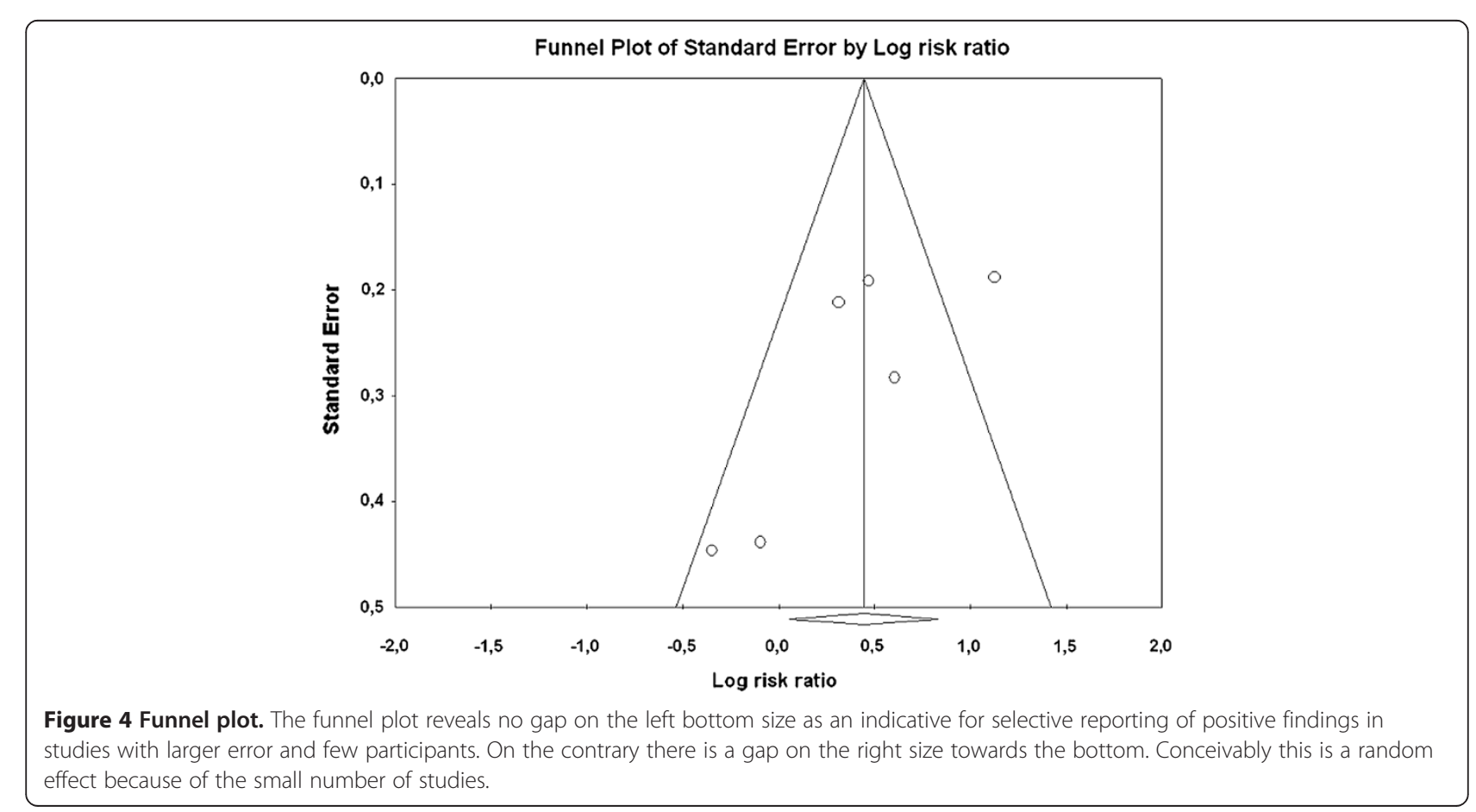


can be worsened by SSRIs. Cognitive impairment or acute psychiatric conditions such as delirium can also get worse through the anticholinergic properties of TCAs. Adverse effects such as agranulocytosis with mianserin [54] should be taken into consideration in the treatment of cancer patients who receive chemotherapy.

There are also many interactions between antidepressants and drugs used in the treatment of cancer. The best studied interactions are these between SSRIs and tamoxifen (a Selective Estrogen Receptor Modulator or SERM), which is metabolized by CYP2D6 into its active form endoxifen [55]. Antidepressants such as paroxetine and duloxetine can inhibit the CYP2D6 cytochrome and thus the formation of the active metabolite endoxifen [56].

\section{Limitations}

The heterogeneity between studies was substantial $\left(\mathrm{I}^{2}=71 \%\right.$ with $95 \%$ CI: $\left.54 \%-82 \%\right)$. As recommended in the Cochrane guidelines (see above), the meta-analysis was recalculated excluding an outlying value (as part of a sensitivity analysis). The efficiency remained significant even after removing an extreme high value $\left(M^{*}=1.39\right.$, $\mathrm{p}=0.008)$. The heterogeneity fell to $10 \%$ which is considered to be of no importance. Thus, heterogeneity affects psychopharmacological studies in cancer patients. Nevertheless, the overall therapeutic effects seem to be consistent across studies.

The reliability of these results is limited by the small number of randomized controlled studies. A larger number of studies are needed to get safe conclusions. The small number of studies and participants can be attributed among other reasons to the preference of the patients and the clinicians for non-blinded treatment, as reported by Musselmann et al. [41]. This may explain the large number of open label studies found in the search in the databases (which are not presented here). Another factor which limits the validity of our results is the quality of the studies. The average risk for bias in these studies could be described as "unclear." As shown in the risk for bias graph (Figure 3), the group of studies was relatively homogenous as regards to this issue. Other limitations of this meta-analysis are the use of different depression rating scales and the different response criteria used by the authors.

\section{Conclusions}

Considering the high prevalence of depression and its impact on mortality and quality of life in cancer patients, it is a matter of concern that only a few trials assessing antidepressant efficacy are available. Given this limitation, we found that antidepressants are effective in the treatment of depression or depressive symptoms in patients with cancer. A minimum of depressive symptoms' severity may be required for the patients to benefit from the use of antidepressants. Though a larger effect size of mianserin in comparison to SSRIs in the subgroup analysis has been shown, no recommendation can be made for one antidepressant type over another. A quantification of tolerability, as ascertained by comparing the number of patients with adverse effects, was not possible because of the missing data. The number of drop outs did not differ significant between the intervention and the control group.

There are difficulties in defining the diagnosis of clinical depression in cancer patients. Symptoms such as fatigue, sadness, worry, and pain are reported by depressed patients as well as in patients with advanced disease. Practical issues such as the ability of physicians to recognize patients with depression should also be considered. Reliable single- or two-item questionnaires have been developed for this purpose. The detection of depressive symptoms might be more important than the exact diagnosis of clinical depression. The current metaanalysis suggests further that antidepressants could be effective in treating sub-clinical depression. However, studies with larger samples are needed in order to verify such conclusion before general clinical recommendations can be derived.

\section{Appendixes \\ Appendix A \\ Listing of the studies}

After scanning 7,000 references and screening 38 articles that seemed appropriate 9 trials could be identified to fulfill the study inclusion criteria. They were further categorized into 2 clusters:

\section{A. Head-to-head trials}

Three RCTs compared two antidepressants with each other (head-to-head trials). These studies did not include a placebo control group.

Holland et al., 1998

Number of patients: 40 patients were recruited and 38 ones of these were randomized (21 patients to the fluoxetine and 17 to the desipramine group). Type of cancer/Stages: Breast cancer. Stages: II, III, IV.

Duration: six weeks

Evaluation tools: the Hamilton Depression Rating Scale (17 item HAM-D), the Clinical and Patient's Global Impression scales (CGI and PGI), the Hamilton Anxiety Rating scale (HAM-A), the Functional Living Index for Cancer (FLIC), the Memorial Pain Assessment Card (MPAC) and the SF-36 Health Survey.

Inclusion criteria: Major depressive episode or adjustment disorder with depressed mood and scores over 14 on the first 17 items of HAM-D. 
Response criteria: a statistically significant baseline to endpoint change in HAM-D.

Design: double blind RCT with ITT analysis, LOCF approach.

Results: There was a significant improvement in the HAM-D scores in both group as evidenced by baseline-to-endpoint changes $(\mathrm{p}<0.001)$. ANOVA showed no significant difference between fluoxetine and desipramine. Similar improvement was also observed in the HAM-A. There were no significant differences in the dropout rates in the fluoxetine and desipramine group $(28.6 \%$ and $41.2 \%$, respectively). The only adverse effect revealing a significance difference was dry mouth reported by $14(66.6 \%)$ patients in the fluoxetine group and $4(23.5 \%)$ patients in the desipramine group.

Pezzela et al., 2001

Number of patients: 179 patients were randomized into either the paroxetine group ( $\mathrm{n}=$ $89)$ or the amitiptyline group $(\mathrm{n}=90) .88$ patients from the first and 87 from the second group received medication and were included in the ITT analysis.

Type of cancer/Stages: Breast cancer, any stage.

Duration: eight weeks

Table 5 Criteria to assess the risk for bias

\begin{tabular}{|c|c|c|}
\hline Domain & Description & $\begin{array}{l}\text { Review } \\
\text { author's } \\
\text { judgement }\end{array}$ \\
\hline $\begin{array}{l}\text { Sequence } \\
\text { generation }\end{array}$ & $\begin{array}{l}\text { Describe the method } \\
\text { used to generate the } \\
\text { allocation sequence }\end{array}$ & $\begin{array}{l}\text { Was the allocation } \\
\text { sequence adequately } \\
\text { generated? (Yes, No, } \\
\text { Unclear) }\end{array}$ \\
\hline $\begin{array}{l}\text { Allocation } \\
\text { concealment }\end{array}$ & $\begin{array}{l}\text { Describe the method } \\
\text { used to conceal the } \\
\text { allocation sequence }\end{array}$ & $\begin{array}{l}\text { Was allocation } \\
\text { adequately concealed? } \\
\text { (Yes, No, Unclear) }\end{array}$ \\
\hline $\begin{array}{l}\text { Blinding of } \\
\text { participants, } \\
\text { personnel, and } \\
\text { outcome }\end{array}$ & $\begin{array}{l}\text { Describe all measures } \\
\text { used to blind participants } \\
\text { and personnel }\end{array}$ & $\begin{array}{l}\text { Was knowledge of the } \\
\text { allocated intervention } \\
\text { adequately prevented } \\
\text { during the study? } \\
\text { (Yes, No, Unclear) }\end{array}$ \\
\hline $\begin{array}{l}\text { Incomplete } \\
\text { outcome data }\end{array}$ & $\begin{array}{l}\text { Describe the } \\
\text { completeness of } \\
\text { outcome data for each } \\
\text { main outcome including } \\
\text { attrition and exclusions } \\
\text { from the analysis. }\end{array}$ & $\begin{array}{l}\text { Were incomplete outcome } \\
\text { data adequately } \\
\text { addressed? (Yes, No, } \\
\text { Unclear) }\end{array}$ \\
\hline $\begin{array}{l}\text { Selective } \\
\text { outcome } \\
\text { reporting }\end{array}$ & $\begin{array}{l}\text { State how the possibility } \\
\text { of selective outcome } \\
\text { reporting was examined } \\
\text { by the review authors } \\
\text { and what was found. }\end{array}$ & $\begin{array}{l}\text { Are reports of the study } \\
\text { free of suggestion of } \\
\text { selective outcome } \\
\text { reporting? (Yes, No, } \\
\text { Unclear) }\end{array}$ \\
\hline $\begin{array}{l}\text { Other sources of } \\
\text { bias }\end{array}$ & $\begin{array}{l}\text { State any important } \\
\text { concerns about bias not } \\
\text { addressed in the other } \\
\text { domains. }\end{array}$ & $\begin{array}{l}\text { Was the study apparently } \\
\text { free of other problems } \\
\text { that could put it at high } \\
\text { risk of bias? }\end{array}$ \\
\hline
\end{tabular}

Study-wise evaluation of Risk of Bias:
Table 6 Pezella et al., 2001

\begin{tabular}{|c|c|c|}
\hline Domain & Description & $\begin{array}{l}\text { Review } \\
\text { author's } \\
\text { judgement }\end{array}$ \\
\hline Sequence generation & $\begin{array}{l}\text { Randomized study, method not } \\
\text { described. }\end{array}$ & "Unclear" \\
\hline $\begin{array}{l}\text { Allocation } \\
\text { concealment }\end{array}$ & $\begin{array}{l}\text { Double dummy technique was } \\
\text { used. Assignment envelopes are not } \\
\text { described. }\end{array}$ & "Unclear" \\
\hline $\begin{array}{l}\text { Blinding of } \\
\text { participants, personnel, } \\
\text { and outcome }\end{array}$ & $\begin{array}{l}\text { Double blind study. More frequent } \\
\text { anticholinegic AEs in the } \\
\text { amitriptyline group, which could } \\
\text { break blinding. }\end{array}$ & "Unclear" \\
\hline $\begin{array}{l}\text { Incomplete } \\
\text { outcome data }\end{array}$ & $\begin{array}{l}\text { Main outcome was the MADRS } \\
\text { score. } 16 \text { withdrawals in the } \\
\text { paroxetine group and } 19 \text { in the } \\
\text { amitriptyline group. } 9 \text { dropouts in } \\
\text { the paroxetine group and } 10 \text { in the } \\
\text { amitriptyline group due to AEs. } \\
\text { Other reasons for withdrawals are } \\
\text { not reported. Analysis according to } \\
\text { ITT principle. Missing data } \\
\text { imputation method: LOCF. }\end{array}$ & "No" \\
\hline $\begin{array}{l}\text { Selective outcome } \\
\text { reporting }\end{array}$ & $\begin{array}{l}\text { Protocol is not available. All pre- } \\
\text { specified outcomes of interest are } \\
\text { reported in the pre-specified way. }\end{array}$ & "Yes" \\
\hline Other sources of bias & $\begin{array}{l}\text { The study appears to be free of } \\
\text { other sources of bias. }\end{array}$ & "Yes" \\
\hline
\end{tabular}

Evaluation tools: Montgomery and Asberg Depression Rating Scale (MADRS), the Clinical Global Impression (CGI), the functional living index: cancer (FLIC) and the patient's global evaluation (PGE).

Table 7 Holland et al., 1998

\begin{tabular}{|c|c|c|}
\hline Domain & Description & $\begin{array}{l}\text { Review } \\
\text { author's } \\
\text { judgement }\end{array}$ \\
\hline Sequence generation & $\begin{array}{l}\text { Randomized study, randomization } \\
\text { method not described. }\end{array}$ & "Unclear" \\
\hline $\begin{array}{l}\text { Allocation } \\
\text { concealment }\end{array}$ & Method is not described. & "Unclear" \\
\hline $\begin{array}{l}\text { Blinding of } \\
\text { participants, personnel, } \\
\text { and outcome }\end{array}$ & $\begin{array}{l}\text { Double blind study. More frequent } \\
\text { anticholinergic effects in the } \\
\text { fluoxetine group. Issue is not } \\
\text { sufficiently addressed by the authors. }\end{array}$ & "Unclear" \\
\hline $\begin{array}{l}\text { Incomplete outcome } \\
\text { data }\end{array}$ & $\begin{array}{l}\text { The main outcome war the raw } \\
\text { baseline to endpoint differences in } \\
\text { HAM-D. There were } 6 \text { dropouts in } \\
\text { the fluoxetine group, all due to AEs. } \\
\text { There were } 7 \text { dropouts in the } \\
\text { desipramine, } 4 \text { due to AEs, } 3 \text { to } \\
\text { unknown reasons. Analysis } \\
\text { according to ITT principle. Missing } \\
\text { data imputation method: LOCF. }\end{array}$ & "No" \\
\hline $\begin{array}{l}\text { Selective outcome } \\
\text { reporting }\end{array}$ & $\begin{array}{l}\text { Study protocol is not available. All } \\
\text { pre-specified outcomes are reported } \\
\text { in the pre-specified way. No } \\
\text { response criteria were defined. } \\
\text { Improvement was not pre-specified. }\end{array}$ & "No" \\
\hline Other sources of bias & $\begin{array}{l}\text { The study seems to be free from } \\
\text { other sources of bias. }\end{array}$ & "Yes" \\
\hline
\end{tabular}


Table 8 Cancurtaran et al., 2008

\begin{tabular}{|c|c|c|}
\hline Domain & Description & $\begin{array}{l}\text { Review } \\
\text { author's } \\
\text { judgement }\end{array}$ \\
\hline Sequence generation & $\begin{array}{l}\text { Randomization method is not } \\
\text { described. Patients who refused to } \\
\text { take medication formed a control } \\
\text { group. The allocation by preference } \\
\text { of the participants is problematic in } \\
\text { randomized studies. }\end{array}$ & "No" \\
\hline $\begin{array}{l}\text { Allocation } \\
\text { concealment }\end{array}$ & $\begin{array}{l}\text { Not described for the two drug } \\
\text { groups. No blinding for the control } \\
\text { group. }\end{array}$ & "No" \\
\hline $\begin{array}{l}\text { Blinding of } \\
\text { participants, personnel, } \\
\text { and outcome }\end{array}$ & No blinding for the control group. & "No" \\
\hline $\begin{array}{l}\text { Incomplete outcome } \\
\text { data }\end{array}$ & $\begin{array}{l}\text { The main outcome was the HAM-D } \\
\text { score and single symptom scales } \\
\text { score for nausea, pain, vomiting. } 4 \\
\text { Dropouts in the mirtazapine group, } \\
4 \text { in the imipramine group, ten } \\
\text { dropouts in the control group. No } \\
\text { ITT analysis. Missing data } \\
\text { imputation method: completers' } \\
\text { analysis. }\end{array}$ & "No" \\
\hline $\begin{array}{l}\text { Selective outcome } \\
\text { reporting }\end{array}$ & $\begin{array}{l}\text { No study protocol available. All pre- } \\
\text { specified outcomes are reported in } \\
\text { the pre-specified way. No pre- } \\
\text { specified criteria for response or } \\
\text { improvement. }\end{array}$ & "No" \\
\hline Other sources of bias & $\begin{array}{l}\text { The study seems to be free from } \\
\text { other sources of bias. }\end{array}$ & "Yes" \\
\hline
\end{tabular}

Inclusion criteria: The patients should fulfill the ICD-10 criteria for depressive episode and have a minimum score of 16 in the MADRS.

Response criteria: At least 50\% decrease from baseline in MADRS score

Design: double blind RCT, ITT analysis, LOCF approach.
Results: 38 patients in the paroxetine group $(43.7 \%)$ and 33 patients in the amitriptyline group (37.8\%) were responders $(\mathrm{p}=0.441) .47$ patients in the first and 53 from the second group reported at least one adverse experience. There were 16 withdrawals in the paroxetine group and 19 withdrawals in the amitriptyline group. The study showed that paroxetine and amitriptyline were similar in efficacy and tolerability.

\section{Cancurtaran et al., 2008}

Number of patients: 53 patients participated in this study: 20 patients in the mirtazapine group, 13 patients in the imipramine group and 20 patients in a control group without medication or placebo (only supportive psychotherapy).

Type of cancer/Stages: The type and stage of cancer are not further specified.

Duration: six seeks

Evaluation tools: The patients were screened with the Structured Clinical Interview for Diagnostic (SCID). The Hospital Anxiety and Depression Scale (HADS) was administered for assessment of depression and anxiety during the study.

Inclusion criteria: Major depressive disorder, adjustment disorder, anxiety disorders. Response criteria: The authors reported on the statistical significance of the rating differences between baseline and endpoint in each group. Design: double blind RCT (not blinded for those who denied medication and received only psychotherapy), completers' analysis.

Results: The patients in the mirtazapine group improved significantly after the six weeks in the total HADS scores $(\mathrm{p}=0.014)$, the anxiety subscale $(\mathrm{p}=0.04)$ and the depression subscale $(\mathrm{p}=0.008)$.

Table 9 Costa et al., 1985

\begin{tabular}{|c|c|c|}
\hline Domain & Description & $\begin{array}{l}\text { Review } \\
\text { author's } \\
\text { judgement }\end{array}$ \\
\hline Sequence generation & The randomization method is not described. & "Unclear" \\
\hline Allocation concealment & Exact method is not described. & "Unclear" \\
\hline $\begin{array}{l}\text { Blinding of participants, } \\
\text { personnel, and outcome }\end{array}$ & Double blind trial. The issue is not adequately addressed. & "Unclear" \\
\hline Incomplete outcome data & $\begin{array}{l}\text { The main outcome was the HDRS score. } 7 \text { dropout in the mianserin group (MG) and } 15 \text { in the } \\
\text { placebo group (PG). Reasons for withdrawal: } 1 \text { in each group due to AEs, } 2 \text { in PG due to lack of } \\
\text { efficacy, the treatment by one patient in the PG was interrupted by the investigator, } 2 \text { in MG and } 4 \\
\text { MG ended the anticancer treatment, } 2 \text { in MG due to cancer complications, } 1 \text { in MG and } 2 \text { in PG due } \\
\text { to temporary withdrawal from the anticancer treatment, } 2 \text { in PG refused anticancer therapy and } \\
\text { were dismissed, } 3 \text { in PG had problems at home and } 1 \text { in MG died. The authors used an ITT analysis. } \\
\text { Missing data imputation method: LOCF approach. Proportionally about one third (30\%) of the } \\
\text { patients were dropouts, which can induce bias in intervention effect estimate. }\end{array}$ & "No" \\
\hline Selective outcome reporting & $\begin{array}{l}\text { No study protocol available. All pre-specified outcomes are reported in the pre-specified way. The } \\
\text { response criteria are not pre-specified. }\end{array}$ & "No" \\
\hline Other sources of bias & The study seems to be free of other sources of bias. & "Yes" \\
\hline
\end{tabular}


Table 10 Van Heeringen et al., 1996

\begin{tabular}{|c|c|c|}
\hline Domain & Description & $\begin{array}{l}\text { Review author's } \\
\text { judgement }\end{array}$ \\
\hline Sequence generation & The randomization method is not described & "Unclear" \\
\hline Allocation concealment & The exact method is not described. & "Unclear" \\
\hline $\begin{array}{l}\text { Blinding of participants, } \\
\text { personnel, and outcome }\end{array}$ & The study is defined as double blind. The issue is not addressed by the authors. & "Unclear" \\
\hline Incomplete outcome data & $\begin{array}{l}\text { The main outcome was the HDRS score. There were } 6 \text { drop outs in the mianserin group and } \\
15 \text { dropouts in the placebo group. } 2 \text { patients in the mianserin group and } 11 \text { in the placebo } \\
\text { group withdrew due to lack of efficacy. } 2 \text { dropouts in the mianserin group and } 4 \text { in the } \\
\text { placebo group due to AEs. ITT analysis. Missing data imputation method: LOCF approach. Over } \\
\text { one third of the patients withdrew from the study (38\%), No study protocol available. All pre- } \\
\text { specified outcomes are reported in the pre-specified way. }\end{array}$ & "No" \\
\hline Selective outcome reporting & No study protocol available. All pre-specified outcomes are reported in the pre-specified way. & "Yes" \\
\hline Other sources of bias & The study seems to be free of other sources of bias. & "Yes" \\
\hline
\end{tabular}

The patients in the other two groups did not show any significant improvement.

\section{B. Placebo controlled trials}

The pharmacological agents that were used in these six studies were: mianserin (two trials), fluoxetine (three trials) and paroxetine (one trial). Musselman et al. used an additional third group with cancer patients receiving desipramine.

\section{Mianserin}

Costa 1985 and van Heeringen 1996 compared mianserin with placebo. Both reported a significant improvement of the depressive symptoms. Mianserin is a tetracyclic antidepressant agent and is considered as the predecessor of mirtazapine.

\section{Costa et al., 1985}

Number of patients: 73 patients participated in this study (36 in the drug group and 37 in the placebo group).

Type of cancer/Stages: Gynecological cancers, stages II, III, IV
Duration: four weeks

Screening/Evaluation tools: Zung Self-Rating

Depression Scale (ZSRDS), Hamilton Depression

Rating Scale. Secondary tools measures: Clinical

Global Impression of Illness Severity (CGI-S).

Inclusion Criteria: ZSRDS over 41 and HDRS

score over 16.

Response criteria: nor reported.

Design: Double blind RCT, ITT analysis, LOCF

approach.

Results: 28 of the 36 patients of the mianserin

group were responders. There were only 18 responders among the 37 participants in the placebo group (response evaluated according to the CGI scores). This difference was statically significant $(\mathrm{P}<0.025$, Chi squared $=6.62)$. The primary outcome was based on the scores of HDRS. There were 7 dropouts in the mianserin group and 15 in the placebo group. 17 patients from the drug group and 11 from the placebo

Table 11 Razavi et al., 1996

\begin{tabular}{|c|c|c|}
\hline Domain & Description & $\begin{array}{l}\text { Review author's } \\
\text { judgement }\end{array}$ \\
\hline Sequence generation & Randomization method is not described. & "Unclear" \\
\hline Allocation concealment & The exact method is not described. & "Unclear" \\
\hline $\begin{array}{l}\text { Blinding of participants, } \\
\text { personnel, and outcome }\end{array}$ & Double blind trial. The authors do not address this issue. & "Unclear" \\
\hline \multirow[t]{2}{*}{ Incomplete outcome data } & $\begin{array}{l}\text { The main outcome was the number of patients with success criteria (HADS score } \leq 8 \text { ) and with } \\
\text { response criteria }(\geq 50 \% \text { improvement in HADS score). There were } 15 \text { dropouts in the fluoxetine } \\
\text { group (FG) and } 7 \text { dropouts in the placebo group (PG). The reasons for dropouts in the FG } \\
\text { were: } 7 \text { due to AEs, } 3 \text { decided to interrupt their participation for unknown reasons, } 1 \text { due to } \\
\text { alcohol abuse, and } 4 \text { for other reasons: }\end{array}$ & "Unclear" \\
\hline & $\begin{array}{l}\text { (Non-compliance, investigator's decision, lost to follow-up). The reasons for dropouts in the PG } \\
\text { were: } 2 \text { due to concomitant events, } 4 \text { for unknown reasons, } 1 \text { for psychiatric reasons. The } \\
\text { authors used an ITT basis for the success and response rates. The exact missing data } \\
\text { imputation method is not being reported. }\end{array}$ & \\
\hline Selective outcome reporting & No study protocol available. All pre-specified outcomes are reported in the pre-specified way. & "Yes" \\
\hline Other sources of bias & The study seems to be free of other sources of bias. & "Yes" \\
\hline
\end{tabular}


Table 12 Fisch et al., 2003

\begin{tabular}{|c|c|c|}
\hline Domain & Description & $\begin{array}{l}\text { Review author's } \\
\text { judgement }\end{array}$ \\
\hline Sequence generation & Randomization by means of a preprinted randomization table. & "Yes" \\
\hline Allocation concealment & The exact method is not described. & "Unclear" \\
\hline $\begin{array}{l}\text { Blinding of participants, } \\
\text { personnel, and outcome }\end{array}$ & "The issue is not addressed by the authors. & "Unclear" \\
\hline Incomplete outcome data & $\begin{array}{l}163 \text { patients were randomized and } 159 \text { allocated to receive medication. The patients were } \\
\text { included in the analysis if they provided data at least two assessments (baseline and one of the } \\
\text { next four). } 64 \text { patients were evaluable in the fluoxetine group and } 65 \text { in the placebo group. } \\
\text { The reasons for dropouts are not fully presented. The authors used a modification of } \\
\text { completers' analysis. The missing data imputation method was the best change score, which is } \\
\text { defined as the difference between the baseline score and the average of the best consecutive } \\
\text { scores. According to the authors' opinion this is a valid statistical method for longitudinal data. } \\
\text { To our opinion the best change score belongs to the inappropriate imputation methods. }\end{array}$ & "No" \\
\hline Selective outcome reporting & No study protocol available. All pre-specified outcomes are reported in the pre-specified way. & "Yes" \\
\hline Other sources of bias & $\begin{array}{l}\text { There were many loss of data especially at the fourth assessment. This could influence the } \\
\text { intervention effect estimate. }\end{array}$ & "No" \\
\hline
\end{tabular}

group reported side effects. This difference was not statistically significant (Chi squared $=2.11$ ).

Van Heeringen and Zivkov, 1996

Number of patients: 55 participants in the study (28 in the mianserin group and 27 in the placebo group)

Type of cancer/Stages: Breast cancer. Stages I, II Duration: 7 weeks

Screening tool: Hamilton Depression Rating Scale (HDRS)

Inclusion Criteria: HDRS score over 16

Response criteria: 50\% decrease in baseline HRDS scores

Design: double blind RCT, ITT analysis, LOCF approach.

Results: 19 patients from the 28 ones in the mianserin group and 10 patients from the 27 ones in the placebo group were responders. This difference was statistically significant $(p=0.044$, Fisher's exact test). Significantly more placebo treated patients $(n=15)$ than mianserin treated patients $(n=6)$ terminated prematurely the study $(\mathrm{P}=0.014$, Fisher's exact test). No significant differences were found between numbers of patients complaining of at least one adverse effect (AE) at any assessment point. At day 42, 11 mianserin- and 17 placebo- treated patients reported AEs $(\mathrm{P}=0.14)$.

\section{Fluoxetine}

Three RTCs compared fluoxetine with placebo.

Razavi et al., 1996

Number of patients: 91 patients participated in this study (45 in the fluoxetine group and 46 in the placebo group)

Type of cancer/Stages: Any kind of cancer (mainly gynecological), any stage (95\% without metastases).

Duration: five weeks

Screening tool: Hospital Anxiety and Depression Scale (HADS). Other measures: the Montgomery

Table 13 Navari et al., 2007

\begin{tabular}{|c|c|c|}
\hline Domain & Description & $\begin{array}{l}\text { Review author's } \\
\text { judgement }\end{array}$ \\
\hline Sequence generation & The randomization method is not described. & "Unclear" \\
\hline Allocation concealment & The exact method is not described. & "Unclear" \\
\hline $\begin{array}{l}\text { Blinding of participants, } \\
\text { personnel, and outcome }\end{array}$ & Double blind trial. The issue is not addressed by the authors. & "Unclear" \\
\hline Incomplete outcome data & $\begin{array}{l}\text { The main outcome was the scores on FACT-G and BZSDS. } 193 \text { patients enrolled in the study, } \\
183 \text { were available at the first follow-up and } 180 \text { at the second. The reasons for dropouts are } \\
\text { not reported. The authors used a completers' analysis, which was not pre-specified in the } \\
\text { description of the study. }\end{array}$ & "No" \\
\hline Selective outcome reporting & $\begin{array}{l}\text { The scores of the FACT-G and BZSDS are not reported. The results are presented as numbers of } \\
\text { patients with significant improvement, which is not pre-specified in the description of the } \\
\text { study. The AEs are also not reported. }\end{array}$ & "No" \\
\hline Other sources of bias & The study seems to be free from other sources of bias. & "Yes" \\
\hline
\end{tabular}


Table 14 Musselmann et al., 2006

\begin{tabular}{|c|c|c|}
\hline Domain & Description & $\begin{array}{l}\text { Review author's } \\
\text { judgement }\end{array}$ \\
\hline Sequence generation & The randomization method is not described & "Unclear" \\
\hline Allocation concealment & The exact method is not described. & "Unclear" \\
\hline $\begin{array}{l}\text { Blinding of participants, } \\
\text { personnel, and outcome }\end{array}$ & Double blind study. The issue is not addressed by the authors. & "Unclear" \\
\hline Incomplete outcome data & $\begin{array}{l}\text { The main outcome was the number of patients with response ( } \geq 50 \% \text { improvement in the } \\
\text { HAM-D scale) and with remission (HAM-D } \leq 7) \text {. There were } 14 \text { dropouts in a total of } 40 \\
\text { participants ( } 40 \% \text { ). Reasons for dropouts were: AEs ( } 2 \text { in paroxetine group, } 1 \text { in desipramine } \\
\text { group and } 2 \text { in placebo group), lack of efficacy ( } 2 \text { in paroxetine and } 2 \text { in placebo group), } \\
\text { patients' wish to discontinue ( } 2 \text { in placebo group), one was lost to follow-up and one from the } \\
\text { placebo group could not ingest any medication. The analysis was done on an ITT base. The } \\
\text { missing data imputation method was the LOCF. }\end{array}$ & "No" \\
\hline Selective outcome reporting & No study protocol available. All pre-specified outcomes are reported in the pre-specified way. & "Yes" \\
\hline Other sources of bias & Small number of participants. & "No" \\
\hline
\end{tabular}

and Asberg Depression Scale (MADRS), the Hamilton Anxiety Scale (HAS), the revised Symptom Checklist (SCL-90R) and the Spitzer Quality of Life Index (SQOLI).

Inclusion Criteria: a HADS score over 13

Response criteria: a $50 \%$ decrease or more in the baseline HADS scores

Design: double blind RCT, completers' analysis. Results: The HADS response rates were $18 \%$ in the fluoxetine group and $20 \%$ in the placebo group. The success rates (HADS scores under 8 at the end of the trial) were $11 \%$ (5 patients) and $7 \%$ (3 patients) in the drug and placebo group respectively. As a secondary outcome the author reported the response rates in both groups according to MADRS scale (50\% improvement): these were $31 \%$ (14 patients) for the fluoxetine group and 33\% (15 patients) in the placebo group. These differences were not statistically significant. Significantly more drop outs were observed in the drug group $(n=15)$ than in the placebo group $(n=7)$ (Chi Square test; $\mathrm{P}=0.04$ ). $67 \%$ from the fluoxetine group reported at least one $\mathrm{AE}$ compared to $59 \%$ in the placebo group (not statistically significant difference: $\mathrm{P}=0.43$ ).
Fisch et al., 2003

Number of patients: 163 patients participated in the study (83 patients in the fluoxetine group and 80 patients in the placebo group).

Type of cancer/Stages: Any type of cancer in advanced stage.

Duration: twelve weeks

Screening tool: The Two Question Screening

Survey (TQSS) was used to assess mood and anhedonia. The two questions are: "During the past month have you been bothered by feeling down, depressed or hopeless?" and "During the past month have you been bothered by having little interest or pleasure in doing things?" There are five possible answers which are assigned values from 0 to 4 :

0 not at all, 1 a little bit, 2 somewhat, 3 quite a bit, 4 very much.

For the evaluation of depression and quality of life in the participants the following tools were used: the Functional Assessment of Cancer Therapy General instrument (FACT-G), the Functional Assessment of Chronic Illness Therapy Spiritual and the Brief Zung Self

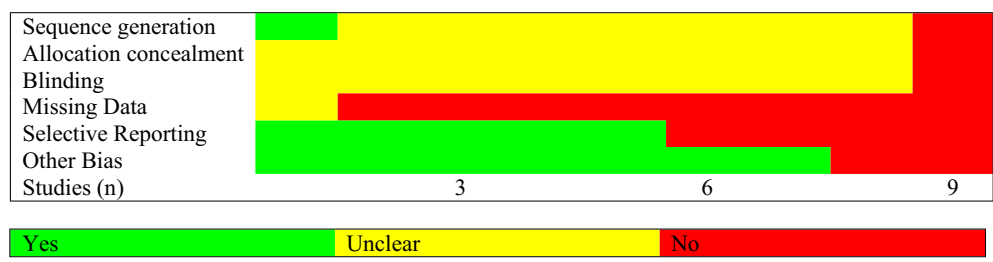

Figure 5 Risk of bias graph for all 9 studies reviewed. Most studies did not describe the methods used to generate and conceal the allocation sequence. All studies were defined as double blind, but the exact blinding method was not described in any of them. No study used an appropriate method to address the issue of missing data. As one can see the studies were relative uniform as far as the issue of risk of bias is concerned. 
Table 15 Subgroup analysis for inclusion criteria

\begin{tabular}{|c|c|c|c|c|c|c|}
\hline \multirow[t]{2}{*}{ Author } & \multirow[t]{2}{*}{ Year } & \multirow[t]{2}{*}{ Verum } & \multicolumn{2}{|c|}{ Verum } & \multicolumn{2}{|c|}{ Placebo } \\
\hline & & & Participants & Responders & Participants & Responders \\
\hline \multicolumn{7}{|c|}{ Group A: Clinical depression as an inclusion criterion } \\
\hline Costa & 1985 & Mianserin & 36 & 28 & 37 & 18 \\
\hline Van Heeringen & 1996 & Mianserin & 28 & 19 & 27 & 10 \\
\hline Razavi & 1996 & Fluoxetine & 35 & 8 & 46 & 9 \\
\hline Musselmann & 2006 & Paroxetine/desipramine & 24 & 11 & 11 & 6 \\
\hline Total & & & 133 & 66 & 121 & 43 \\
\hline \multicolumn{7}{|c|}{ Group B: Clinical depression not as an inclusion criterion } \\
\hline Fisch & 2003 & Fluoxetine & 64 & 31 & 65 & 23 \\
\hline Total & & & 64 & 31 & 65 & 23 \\
\hline
\end{tabular}

$\mathrm{RR}_{(\mathrm{A})}=1.42, \mathrm{RR}_{(\mathrm{B})}=1.37\left(\mathrm{Z}_{\text {diff }}=0.19, \mathrm{p}=0.85\right)$.

administered Depression Rating Scale (BZDRS) with 11 items.

Inclusion Criteria: A TQSS score of 2 or greater. Patients with a major depressive episode were excluded.

Response criteria: A best change score of at least -3 in the BZDRS. A best change score is defined as the difference between the baseline score and the average of the best consecutive scores.

Design: Double blind RCT. Computations were made only on patients who completed the baseline questionnaires $(n=159)$ and at least one follow up assessment $(n=129)$. The authors used additionally the generalized estimating equation (GEE) method of regression.

Results: There were data for 129 patients at the end point (64 in the fluoxetine group and 65 in the placebo group). $48 \%(\mathrm{n}=31)$ patients in the fluoxetine group and $36 \%(n=23)$ in the placebo group were responders. This difference was not statistically significant. Reevaluating the data with the GEE method of regression the authors found a significant improvement in the fluoxetine group. There were not any concrete data about the number of dropouts or reported adverse effects in each group.

Navari et al., 2008

Number of patients: 203 patients out of the 357 screened patients qualified for enrolment in this study. From the 193 who enrolled in the study the authors reported on the 180 patients who completed the six month assessment.

Type of cancer/Stages: Breast cancer, stages I, II Duration: six months

Screening tool: The Two Question Screening Survey (TQSS) was used to assess mood and anhedonia. The two questions are: "During the past month have you been bothered by feeling down, depressed or hopeless?" and "During the past month have you been bothered by having little interest or pleasure in doing things?" There five possible answers which are assigned values from 0 to 4 :

0 not at all, 1 a little bit, 2 somewhat, 3 quite a bit, 4 very much.

Table 16 Subgroup analysis for study design (ITT vs. completers' analysis)

\begin{tabular}{|c|c|c|c|c|c|c|}
\hline \multirow[t]{2}{*}{ Author } & \multirow[t]{2}{*}{ Year } & \multirow[t]{2}{*}{ Drug } & \multicolumn{2}{|c|}{ Verum } & \multicolumn{2}{|c|}{ Placebo } \\
\hline & & & Participants & Responders & Participants & Responders \\
\hline \multicolumn{7}{|c|}{ Group A: Analyses by ITT } \\
\hline Costa & 1985 & Mianserin & 36 & 28 & 37 & 18 \\
\hline Van Heeringen & 1996 & Mianserin & 28 & 19 & 27 & 10 \\
\hline Musselmann & 2006 & Paroxetine/desipramine & 24 & 11 & 11 & 6 \\
\hline Total & & & 88 & 58 & 75 & 34 \\
\hline \multicolumn{7}{|c|}{ Group B: analyses not by ITT } \\
\hline Fisch & 2003 & Fluoxetine & 64 & 31 & 65 & 23 \\
\hline Razavi & 1996 & Fluoxetine & 45 & 8 & 46 & 9 \\
\hline Total & & & 109 & 39 & 111 & 32 \\
\hline
\end{tabular}

ITT: intention to treat.

$R R_{(A)}=1.49, R R_{(B)}=1.27\left(Z_{\text {diff }}=0.93, p=0.36\right)$. 
Table 17 Subgroup analysis for cancer stage

\begin{tabular}{|c|c|c|c|c|c|c|}
\hline \multirow[t]{2}{*}{ Author } & \multirow[t]{2}{*}{ Year } & \multirow[t]{2}{*}{ Drug } & \multicolumn{2}{|c|}{ Verum } & \multicolumn{2}{|c|}{ Placebo } \\
\hline & & & Participants & Responders & Participants & Responders \\
\hline \multicolumn{7}{|c|}{ Group A: Any or advanced cancer stage } \\
\hline Costa & 1985 & Mianserin & 36 & 28 & 37 & 18 \\
\hline Fisch & 2003 & Fluoxetine & 64 & 31 & 65 & 23 \\
\hline Razavi & 1996 & Fluoxetine & 45 & 8 & 46 & 9 \\
\hline Musselmann & 2006 & Paroxetine/desipramine & 24 & 11 & 11 & 6 \\
\hline Total & & & 169 & 78 & 159 & 56 \\
\hline \multicolumn{7}{|c|}{ Group B: Early cancer stages } \\
\hline Van Heeringen & 1996 & Mianserin & 28 & 19 & 27 & 10 \\
\hline Total & & & 28 & 19 & 27 & 10 \\
\hline
\end{tabular}

$R_{(A)}=1.29, R_{(B)}=1.83\left(Z_{\text {diff }}=-1.73, p=0.11\right)$.

The quality of life was estimated using the Functional Assessment of Cancer TherapyGeneral (FACT-G) and the depression was estimated with the Brief Zung self administered Depression Rating Scale (BZDRS).

Inclusion Criteria: A TQSS score of 2 or greater. Patients with a major depressive episode were excluded.

Response criteria: "significant improvement" in the BZSRS (not further defined).

Design: double blind RCT, completers' analysis.

Results: 71 patients from the fluoxetine group and 23 patients from the placebo group had a significant improvement in depressive symptoms $(\mathrm{P}<0.0005)$. There were not any data about adverse effects.

\section{Paroxetine}

One study compared paroxetine with desipramine and placebo in depressed cancer patients.

Musselman et al., 2006

Number of patients: 35 patients participated in this study. They were divided into three groups and assigned to receive either paroxetine $(n=13)$ or desipramine $(\mathrm{n}=11)$ or placebo $(\mathrm{n}=11)$.

Type of cancer/Stages: Breast cancer at any stage. Duration: six weeks

Screening tool: a DSM-III-R multi-axial evaluation. Other rating scales used were the 21item Hamilton Rating Scale for Depression (HAM-D), the 14-item Hamilton Rating Scale for Anxiety and the Clinical Global Impression Scale (CGI).

Inclusion Criteria: DSM-III-R criteria for major depression (except duration of illness had to be at least on month), HAM-D score of at least 14 in the first 17 items of the 21-item HAM-D.

Response criteria: A decrease of $\geq 50 \%$ from baseline HAM-D score or a CGI global improvement score $\leq-2$. Clinical remission was defined as a HAM-D score $\leq 7$.

Design: double blind RCT, ITT analysis, LOCF approach

Results: The response rates were: 38\% (5/13

patients) in the paroxetine group, $45 \%(5 / 11$

Table 18 Subgroup analysis for type of antidepressant

\begin{tabular}{|c|c|c|c|c|c|c|}
\hline \multirow[t]{2}{*}{ Author } & \multirow[t]{2}{*}{ Year } & \multirow[t]{2}{*}{ Drug } & \multicolumn{2}{|c|}{ Verum } & \multicolumn{2}{|c|}{ Placebo } \\
\hline & & & Participants & Responders & Participants & Responders \\
\hline \multicolumn{7}{|l|}{ Group A: SSRIs } \\
\hline Fisch & 2003 & Fluoxetine & 64 & 31 & 65 & 23 \\
\hline Razavi & 1996 & Fluoxetine & 45 & 8 & 46 & 9 \\
\hline Musselmann & 2006 & Paroxetine & 13 & 5 & 11 & 6 \\
\hline Total & & & 122 & 44 & 122 & 38 \\
\hline \multicolumn{7}{|c|}{ Group B: Mianserin } \\
\hline Costa & 1985 & Mianserin & 36 & 28 & 37 & 18 \\
\hline Van Heeringen & 1996 & Mianserin & 28 & 19 & 27 & 10 \\
\hline Total & & & 64 & 47 & 64 & 28 \\
\hline
\end{tabular}

$R R_{(A)}=1.16, R R_{(B)}=1.67\left(Z_{\text {diff }}=-2.17, p=0.03\right)$ 
Table 19 List of the final 38 studies

\section{Article}

Goldberg RJ. Management of depression in the patient with advanced cancer. JAMA.246(4):373-6, 1981

Costa D, Mogos I, Toma T. Efficacy of mianserin in the treatment of depression of women with cancer. Acta Psychiatrica Scandinavica. 72 (suppl. 320): 85-92, 1985.

Mathé G, Lopez MD, Fréchet M, de Vassal F, Brienza S, Gastiaburu J. A comparative trial of a MAOI, iproniazide, and a polycyclic agent, mianserine, for the search of the most rapidly and frequently active treatment of depressive syndromes in an oncology service. Biomedicine and Pharmacotherapy. 41(1):13-26, 1987

Maguire P, Hopwood P, Tarrier N, Howell T. Treatment of depression in cancer patients. Acta Psychiatrica Scandinavica Suppl. 320:81-4, 1985.

Evans DL, McCartney CF, Nemeroff CB, Haggerty JJ Jr, Simon JS, Pedersen CA, Holmes V, Droba M, Mason GA, Raft D, et al. Depression in cancer patients. Diagnostic and treatment considerations. North Carolina Medical Journal. 49(10):546-8, 1988.

Silberfarb PM. Psychiatric treatment of the patient during cancer therapy. CA; A Cancer Journal of Clinicians. 38(3):133-7, 1988.

Evans DL, McCartney CF, Haggerty JJ Jr, Nemeroff CB, Golden RN, Simon JB, Quade D, Holmes V, Droba M, Mason GA, et al. Treatment of depression in cancer patients is associated with better life adaptation: a pilot study. Psychosomatic Medicine. 50(1):73-6, 1988.

Van Heeringen K, Zivkov M. Pharmacological treatment of depression in cance patients. A placebo controlled study of Mianserin. British Journal of Psychiatry. 169: 440.443, 1996.

Razavi D, Allilaire JF, Smith M, Salimpour A., Verra M, Desclaux B, Saltel P, Piollet I, Gauvain-Piquard A., Trichard C, Cordier B, Fresco R, Guillibert E, Sechter D, Orth $J P$, Bouhassira M, Mesters $P$, Blin P. The effect of fluoxetine on anxiety and depression symptoms in cancer patients. Acta Psychiatrica Scandinavia. 94: 205-210, 1996.

Holland JC, Romano SJ, Heiligenstein JH, Tepner RG, Wilson MG. A controlled tria of fluoxetine and desipramine in depressed women with advanced cancer. Psycho-Oncology. 7: 291-200, 1998

Razavi D, Kormoss N, Collard A, Farvacques C, Delvaux N. Comparative study of the efficacy and safety of trazodone versus clorazepate in the treatment of adjustment disorders in cancer patients: a pilot study. The Journal of International Medical Research. 27(6):264-72, 1999.

Musselmann DL, Lawson DH, Gumnick JF, Manatunga AK, Penna S, Goodkin RS, Greiner K, Nemeroff CB, Miller AH. Paroxetine for the prevention of depression induced by high dose interferone alpha. The New England Journal of Medicine. Vol 344, No 13, 2001

Pezella G, Moslinger-Gehmayr R, Contu A. Treatment of depression in patients with breast cancer: a comparison between paroxetine and amitrptyline. Breast Cancer Research and Treatment. 70: 1-10, 2001

Passik SD, Kirsh KL, Theobald D, Donaghy K, Holtsclaw E, Edgerton S, Dugan W. Use of a depression screening tool and a fluoxetine-based algorithm to improve the recognition and treatment of depression in cancer patients. A demonstration project. Journal of Pain and Symptom Management. 24(3):318-27, 2002.

Carr D, Goudas L, Lawrence D, Pirl W, Lau J, DeVine D, Kupelnick B, Miller K. Management of cancer symptoms: pain, depression, and fatigue. Evidence Report/Technology Assessment. 61:1-5, 2002.

Davis MP, Khawam E, Pozuelo L, Lagman R. Management of symptoms associated with advanced cancer: olanzapine and mirtazapine. A World Health Organization project. Expert Review of Anticancer Therapy.

\section{2(4): 365-76, 2002.}

Fisch MJ, Loehrer PJ, Kristeller J, Passik S, Jung SH, Shen SH, Arquette MA, Brames MJ, Einhorn LH. Fluoxetine versus Placebo in advanced cancer outpatients: a double-blinded trial of the Hoosier oncology group. Journal of Clinical Oncology. Vol 21, No 10: 1937-1943, 2003.

\section{Assessment}

Review

\section{RCT included in the review}

No double blind RCT

Antidepressant therapy was administrated together with anxiolytic and supportive psychotherapy

Review

Review

No control group.

\section{$\mathrm{RCT}$ included in the review}

\section{$\mathrm{RCT}$ included in the review}

\section{RCT included in the review}

The efficacy of trazodone cannot be safely proven when it is compared to a benzodiazepine. Depression was not an eligibility criterion.

Prevention study, thus prevention was not an eligibility criterion.

\section{$\mathrm{RCT}$ included in the review}

No RCT.

Review.

Recommendation

\section{RCT included in the review}


Theobald DE, Kirsh KL, Holtsclaw E, Donaghy K, Passik SD. An open label pilot study of citalopram for depression and boredom in ambulatory cancer patients.

\section{Palliat Support Care. 2003 Mar;1(1):71-7.}

Morrow GR, Hickok JT, Roscoe JA, Raubertas RF, Andrews PLR, Flynn PJ, Hynes HE, Banerjee TK, Kirschner JJ, King DK. Differential effects of paroxetine on fatigue and depression: a randomized, double blind trial from the University of Rochester Cancer Center Community Clinical Oncology Program. Journal of Clinical

Oncology. Vol 21, No 24: 4635-4641, 2003

Pae CU, Kim YJ, Won WY, Kim HJ, Lee S, Lee CU, Lee SJ, Kim DW, Lee C, Min WS, Kim CC, Paik IH, Serretti A. Paroxetine in the treatment of depressed patients with haematological malignancy: an open-label study. Human Psychopharmacology. 19(1):25-9, 2004.

Coyne JC, Palmer SC, Shapiro PJ. Prescribing antidepressants to advanced cancer patients with mild depressive symptoms is not justified. Journal of Clinical Oncology. 1;22(1):205-6; author reply 206-8, 2004.

Thangathurai D, Roffey P, Mogos M, Riad M, Mikhail M. Usefulness of desipramine in ICU cancer patients for acute depression. Journal of Palliative Care. 20(4):326, 2004.

Ladd CO, Newport DJ, Ragan KA, Loughhead A, Stowe ZN. Venlafaxine in the treatment of depressive and vasomotor symptoms in women with perimenopausal depression. Depression and Anxiety. 22(2):94-7, 2005.

Roscoe JA, Morrow GR, Hickok JT, Mustian KM, Griggs JJ, Matteson SE, Bushunow P, Qazo R, Smith B. Effect of paroxetine hydrochloride on fatigue and depression in breast cancer patients receiving chemotherapy. Breast Cancer Research and Treatment. 89: 243-249, 2005.

Musselmann DL, Somerset WI, Guo Y, Manatunga AK, Porter M, Penna S, Lewison B, Goodkin R, Lawson K, Lawson D, Evans DL, Nemeroff CB. A doubleblind multicenter parallel-group study of paroxetine, desipramine or placebo in breast cancer patients (stages I, II, III, IV) with major depression. Journal of Clinical Psychiatry. 67: 288-296, 2006.

Kimmick GG, Lovato J, McQuellon R, Robinson E, Muss HB. Randomized, doubleblind, placebo-controlled, crossover study of sertraline (Zoloft) for the treatment of hot flashes in women with early stage breast cancer taking tamoxifen.

The Breast Journal. 12(2):114-22, 2006.

Moss EL, Simpson JS, Pelletier G, Forsyth P. An open-label study of the effects of bupropion SR on fatigue, depression and quality of life of mixed-site cancer patients and their partners. Psychooncology. 15(3):259-67, 2006.

Loibl S, Schwedler K, von Minckwitz G, Strohmeier R, Mehta KM, Kaufmann M. Venlafaxine is superior to clonidine as treatment of hot flashes in breast cancer patients--a double-blind, randomized study. Annals of Oncology.

18(4):689-93, 2007.

Stockler MR, O'Connel R, Nowak AK, Goldstein D, Turner J, Wilcken NRC, Wyld D, Abdi EA, Glasgow A, Beale PJ, Jefford M, Dhillon H, Heritier S, Carter C, Hickie IB, Simes RJ. Effect of sertraline on symptoms and survival in patients with advanced cancer, but without major depression: a placebo controlled double-blind randomized trial. Lancet Oncology. 8: 603-612, 2007.

Raji MA, Barnum PD, Freeman J, Markowitz AB. Mirtazapine for depression and comorbidities in older patients with cancer. Annals of Pharmacotherapy. 41(9):1548-9, 2007.

Cankurtaran ES, Ozalp E, Soygur H, Akbiyik DI, Tuhan L, Alkis N. Mirtazapine improves sleep and lowers anxiety and depression in cancer patients: superiority over imipramine. Supportive Care in Cancer. 16: 1291-1298, 2008.

Torta R, Siri I, Caldera P. Sertraline effectiveness and safety in depressed oncological patients. Supportive Care in Cancer. 16(1):83-91, 2008.

Okamura M, Akizuki N, Nakano T, Shimizu K, Ito T, Akechi T, Uchitomi Y. Clinical experience of the use of a pharmacological treatment algorithm for major depressive disorder in patients with advanced cancer. Psychooncology. 17(2):154-60, 2008.

Ersoy MA, Noyan AM, Elbi H. An open-label long-term naturalistic study of mirtazapine treatment for depression in cancer patients. Clinical Drug Investigation. 28(2):113-20, 2008.
No RCT.

Depression was not an eligibility criterion

No RCT.

Comment.

Comment.

No RCT.

Depression was not an eligibility criterion.

\section{$\mathrm{RCT}$ included in the review.}

Depression was a secondary outcome.

No RCT.

No measures for depression were included.

Depression was not an eligibility criterion.

No RCT.

RCT included in the review.

No RCT.

No RCT.

No RCT. 


\section{Table 19 List of the final 38 studies (Continued)}

Kim SW, Shin IS, Kim JM, Kim YC, Kim KS, Kim KM, Yang SJ, Yoon JS. Effectiveness No RCT.
of mirtazapine for nausea and insomnia in cancer patients with depression.

Psychiatry and Clinical Neuroscience. 62(1):75-83, 2008.

Lydiatt WM, Denman D, McNeilly DP, Puumula SE, Burke WJ. A randomized placebo- controlled trial of citalopram for the prevention of major depression during treatment for head and neck cancer. Archives of Otolaryngology- Head and Neck Surgery. Vol. 134 (No 5), 2008.

Navari RM, Brenner MC, Wilson MN. Treatment of depressive symptoms in patients with early stage breast cancer undergoing adjuvant therapy. Breast Cancer Research and Treatment. 112: 197-201, 2008.

Thangathurai D, Roby J, Roffey P. Treatment of resistant depression in patients with cancer with low doses of ketamine and desipramine. Journal of Palliative Medicine. 13(3):235, 2010

Prevention study, thus depression was not an eligibility criterion.

RCT included in the review.

The authors report on two patients patients) in the desipramine group and 55\% (6/11 patients) in the placebo group $(p=0.91)$. The remission rates were: $23 \%$ (3/11 patients) in the paroxetine group, $45 \%$ (5/11 patients) in the desipramine group and $36 \%$ (4/11 patients) in the placebo group $(\mathrm{p}=0.55)$. There were 14 dropouts by week six: 5 in the paroxetine group, 4 in the desipramine group and 5 in the placebo group.

The most common adverse effects were:

Paroxetine: dry mouth $(n=6)$, nausea $(n=5)$, pain $(n=5)$ Desipramine: dry mouth $(n=8)$, constipation $(n=4)$, headaches $(n=4)$, pain $(n=4)$

Placebo: headache $(n=5)$, pain $(n=5)$, dry mouth $(n=3)$, constipation $(n=3)$.

The difference in side effects among the groups was not significant.

\section{Appendix B}

\section{Assessment of bias}

We used the Cochrane Collaboration's tool for assessing the risk of bias. These criteria may be considered sufficiently strict. This included extracting of six domains and judging them. The consensual authors' judgment were either "Yes", indicating low risk of bias, "No" indicating high risk of bias, or "Unclear" indicating unknown risk of bias. The criteria to assess the studies were: (Tables 5, 6, 7, 8, 9, 10, 11, 12, 13, 14).

In summary, only one study (Fisch et al., 2003) described the exact randomization method. The rest studies defined themselves as randomized, but did not describe the method ("Unclear"). The exact allocation concealment method was not described in any study. All studies were defined as double blind. No article reported which persons in the study were blinded and which were not. All but one studies described an inappropriate missing data imputation method, even the ones who used an ITT-based analysis; the LOCF method can also introduce bias (see Cochrane [31] and www.missingdata.org.uk). In total several indications for Risk of Bias can be observed and most items remained unclear (see Figures 3 and 5).

\section{Appendix C}

\section{Subgroup analysis after outlier exclusion}

1. Eligibility criteria: Depression vs. depressive symptoms Subgroup analysis for inclusion criteria (Table 15).

2. Study design: Intention to treat vs. completers' analysis Subgroup analysis for study design (ITT vs. completers' analysis) (Table 16)

3. Eligibility criteria: Cancer stage

Subgroup analysis for cancer stage (Table 17).

4. Comparison between SSRIs and tetracyclic antidepressants

Subgroup analysis for type of antidepressant (Table 18)

\section{Appendix D}

List of the final 38 studies (Table 19)

Competing interests

The authors declare that they have no competing interests.

\section{Authors' contributions}

Zacharias G. Laoutidis participated in data collection and evaluation, performed the statistical analysis and drafted the manuscript. Klaus Mathiak conceived and designed the study, acquired the funding, participated in and supervised collection of data, and helped to draft the manuscript. Both authors read and approved the manuscript.

\section{Acknowledgements}

The study was supported by the German Research Foundation (DFG; MA2631/4-1). The funders had no role in study design, data collection and analysis, decision to publish, or preparation of the manuscript. We would like to thank Martina Haeck MD for the helpful discussions.

\section{Author details}

'Department of Psychiatry, Psychotherapy and Psychosomatics, RWTH University of Aachen, Bergische Landstrasse 2, 40629 Düsseldorf, Germany. ${ }^{2}$ Department of Psychiatry, University of Düsseldorf, Bergische Landstrasse 2, 40629 Düsseldorf, Germany. ${ }^{3}$ ülich Aachen Research Alliance (JARA-BRAIN)، Pauwelstrasse 30, 52074 Aachen, Germany. ${ }^{4}$ Institute of Neuroscience and Medicine (INM-1), Forschungszentrum Jülich GmbH, Aachen, Germany.

Received: 16 August 2012 Accepted: 9 April 2013

Published: 16 May 2013 


\section{References}

1. Ruttley A, Reid S: Depression in physical illness. Clin Med 2006, 6:533-536.

2. Kroenke K, Theobald D, Wu J, Loza JK, Carpenter JS, Tu W: The association of depression and pain with health-related quality of life, disability, and health care use in cancer patients. J Pain Symp Manag 2010, 40:327-341.

3. Brown LF, Kroenke K, Theobald D, Wu J, Carpenter JS, Tu W: The association of depression and anxiety with health-related quality of life in cancer patients with depression and/or pain. Psychooncology 2010, 19:734-741

4. House A: Mood disorders in the physically ill-problems of definition and measurement. J Psychosom Res 1988, 32:345-353.

5. Mitchel AJ, Chan M, Bhatti H, Halton M, Grassi L, Johannen C, Meader N: Prevalence of depression, anxiety, and adjustment disorder in oncological, haematological, and palliative care settings: a meta-analysis of 94 interview-based studies. Lancet Oncol 2011, 12:160-174.

6. Ng CG, Boks MP, Zainal NZ, de Wit NJ: The prevalence and pharmacotherapy of depression in cancer patients. J Affect Disord 2011, 131:1-7.

7. Punekar RS, Short PF, Moran JR: Use of psychotropic medications by US cancer survivors. Psychooncology 2012, 21:1237-1243.

8. Kübler-Ross E: On Death and Dying. New York: Simon \& Schuster/ Touchstone; 1969

9. Rayner L, Loge JH, Wasteson E, Higginson IJ: EPCRC, European Palliative Care Research Collaborative. The detection of depression in palliative care. Curr Opin Support Palliat Care 2009, 3:55-60.

10. Lederberg MS: Psychooncology. In Kaplan and Sadock, Textbook of Psychiatry, Volume 2. 8th edition. Philadelphia: Lippincott Williams and Wilkins; 2005:2225.

11. Endicott J: Measurement of depression in patients with cancer. Cancer 1984, 53:2243-2248.

12. National Institutes of Health State-of-the-Science Panel, Unützer J, Vernon SW, Patrick DL, Ferketich SL, Frame PS, Harris JJ, Hendricks CB, Levin B, Link MP, Lustig C, McLaughlin J, Ried LD, Turrisi AT 3rd: National institutes of health state-of-the-science conference statement: symptom management in cancer: pain, depression, and fatigue, July 15-17, 2002 J Natl Cancer Inst 2003, 95:1110-7.

13. Chochinov HM, Wilson KG, Enns M, Lander S: Are you depressed? Screening for depression in the terminally ill. Am J Psychiatry 1997, 154:674-676.

14. Carlson LE, Waller A, Mitchell AJ: Screening for distress und unmet needs in patients with cancer: review and recommendations. J Clin Oncol 2012, 30:1160-1177

15. Satin JR, Linden W, Phillips MJ: Depression as a predictor of disease progression and mortality in cancer patients: a meta-analysis. Cancer 2009, 115:5349-5361.

16. Fang F, Fall K, Mittleman MA, Sparén $P$, Ye W, Adami HO, Valdimarsdóttir U: Suicide and cardiovascular death after a cancer diagnosis. New Engl J Med 2012, 366:1310-1318.

17. Andersen BL, Yang HC, Farrar WB, Golden-Kreutz DM, Emery CF, Thornton $L M$, Young DC, Carson WE 3rd: Psychologic intervention improves survival for breast cancer patients: a randomized clinical trial. Cancer 2008, 113:3450-3458.

18. Giese-Davis J, Collie K, Rancourt KM, Neri E, Kraemer HC, Spiegel D: Decrease in depression symptoms is associated with longer survival in patients with metastatic breast cancer: a secondary analysis. J Clin Oncol 2011, 29:413-420.

19. Spiegel D, Butler LD, Giese-Davis J, Koopman C, Miller E, DiMiceli S, Classen CC, Fobair P, Carlson RW, Kraemer HC: Effects of supportive-expressive group therapy on survival of patients with metastatic breast cancer: a randomized prospective trial. Cancer 2007, 110:1130-1138.

20. Kissane DW, Love A, Hatton A, Bloch S, Smith G, Clarke DM, Miach P, Ikin J, Ranieri N, Snyder RD: Effect of cognitive-existential group therapy on survival in early-stage breast cancer. J Clin Oncol 2004, 22:4255-4260

21. Kissane DW, Grabsch B, Clarke DM, Smith GC, Love AW, Bloch S, Snyder RD, Li Y: Supportive-expressive group therapy for women with metastatic breast cancer: survival and psychosocial outcome from a randomized controlled trial. Psychooncology 2007, 16:277-286.

22. Goodwin PJ, Leszcz M, Ennis M, Koopmans J, Vincent L, Guther H, Drysdale E, Hundleby M, Chochinov HM, Navarro M, Speca M, Hunter J: The effect of group psychosocial support on survival in metastatic breast cancer. $N$ Engl J Med 2001, 345:1719-1726.
23. Osborn RL, Demoncada AC, Feuerstein M: Psychosocial interventions for depression, anxiety, and quality of life in cancer survivors: meta-analyses. Int J Psychiat Med 2006, 36:13-34

24. Hart SL, Hoyt MA, Diefenbach M, Anderson DR, Kilbourn KM, Craft LL, Stee $J L$, Cuijpers P, Mohr DC, Berendsen M, Spring B, Stanton AL: Meta-analysis of efficacy of interventions for elevated depressive symptoms in adults diagnosed with cancer. J Natl Cancer Inst 2012, 104:990-1004.

25. Pirl WF: Evidence report on the occurrence, assessment and treatment of depression in cancer patients. J Natl Cancer Inst Monogr 2004, 32:32-39.

26. Rodin G, Lloyd N, Katz M, Green E, Mackay JA, Wong RKS: Supportive care guidelines group of cancer care ontario program in evidence-based care: the treatment of depression in cancer patients: a systematic review. Support Care Cancer 2007, 15:123-136.

27. Williams S, Dale J: The effectiveness of treatment for depression/ depressive symptoms in adults with cancer: a systematic review. $\mathrm{Br} J$ Cancer 2006, 94:372-390

28. Li M, Fitzgerald P, Rodin G: Evidence-based treatment of depression in patients with cancer. J Clin Oncol 2012, 30:1187-1196.

29. Rayner L, Price A, Evans A, Valsraj K, Hotopf M, Higginson IJ: Antidepressants for the treatment of depression in palliative care: systematic review and meta-analysis. Palliat Med 2011, 25:36-51.

30. Iovieno N, Tedeschini E, Ameral VE, Rigatelli M, Papakostas Gl: Antidepressants for major depressive disorder in patients with a comorbid axis-III disorder: a meta-analysis of patient characteristics and placebo response rates in randomized controlled trials. Int Clin Psychopharmacol 2011, 26:69-74.

31. Higgins JPT, Green S: Cochrane Handbook for Systematic Reviews of Interventions 4.2.6 [updated September 2006]. In The Cochrane Library, Volume Issue 4. Chichester, UK: John Wiley \& Sons, Ltd; 2006.

32. Borenstein M, Hedges RV, Higgins JPT, Rothstein HR: Introduction to MetaAnalysis. West Sussex: Wiley Edition; 2009.

33. Holland JC, Romano SJ, Heiligenstein JH, Tepner RG, Wilson MG: A controlled trial of fluoxetine and desipramine in depressed women with advanced cancer. Psychooncology 1998, 7:291-300.

34. Pezella G, Moslinger-Gehmayr R, Contu A: Treatment of depression in patients with breast cancer: a comparison between paroxetine and amitrptyline. Breast Cancer Res Treat 2001, 70:1-10.

35. Cankurtaran ES, Ozalp E, Soygur H, Akbiyik DI, Tuhan L, Alkis N: Mirtazapine improves sleep and lowers anxiety and depression in cancer patients: superiority over imipramine. Support Care Cancer 2008, 16:1291-1298.

36. Costa D, Mogos I, Toma T: Efficacy of mianserin in the treatment of depression of women with cancer. Acta Psychiatrica Scandinavia 1985, 72(suppl. 320):85-92

37. Van Heeringen K, Zivkov M: Pharmacological treatment of depression in cancer patients. A placebo controlled study of mianserine. $\mathrm{Br} J$ Psychiatry 1996, 169:440-443.

38. Razavi D, Allilaire JF, Smith M, Salimpour A, Verra M, Desclaux B, Saltel P, Piollet I, Gauvain-Piquard A, Trichard C, Cordier B, Fresco R, Guillibert E, Sechter D, Orth JP, Bouhassira M, Mesters P, Blin P: The effect of fluoxetine on anxiety and depression symptoms in cancer patients. Acta Psychiatrica Scandinavia 1996, 94:205-210.

39. Fisch MJ, Loehrer PJ, Kristeller J, Passik S, Jung SH, Shen SH, Arquette MA, Brames MJ, Einhorn LH: Fluoxetine versus Placebo in advanced cancer outpatients: a double-blinded trial of the Hoosier oncology group. J Clin Oncol 2003, 21:1937-1943.

40. Navari RM, Brenner MC, Wilson MN: Treatment of depressive symptoms in patients with early stage breast cancer undergoing adjuvant therapy. Breast Cancer Res Treat 2008, 112:197-201.

41. Musselmann DL, Somerset WI, Guo Y, Manatunga AK, Porter M, Penna S, Lewison B, Goodkin R, Lawson K, Lawson D, Evans DL, Nemeroff CB: A double-blind multicenter parallel-group study of paroxetine, desipramine or placebo in breast cancer patients (stages I, II, III, IV) with major depression. J Clin Psychiatry 2006, 67:288-296.

42. Morrow GR, Hickok JT, Roscoe JA, Raubertas RF, Andrews PLR, Flynn PJ, Hynes HE, Banerjee TK, Kirschner JJ, King DK: Differential effects of paroxetine on fatigue and depression: a randomized, double blind trial from the University of Rochester Cancer Center Community Clinical Oncology Program. J Clin Oncol 2003, 21:4635-4641.

43. Roscoe JA, Morrow GR, Hickok JT, Mustian KM, Griggs JJ, Matteson SE, Bushunow P, Qazo R, Smith B: Effect of paroxetine hydrochloride on 
fatigue and depression in breast cancer patients receiving chemotherapy. Breast Cancer Res Treat 2005, 89:243-249.

44. Stockler MR, O'Connel R, Nowak AK, Goldstein D, Turner J, Wilcken NRC, Wyld D, Abdi EA, Glasgow A, Beale PJ, Jefford M, Dhillon H, Heritier S, Carter C, Hickie IB, Simes RJ: Effect of sertraline on symptoms and survival in patients with advanced cancer, but without major depression: a placebo controlled double-blind randomized trial. Lancet Oncol 2007, 8:603-612.

45. Musselmann DL, Lawson DH, Gumnick JF, Manatunga AK, Penna S, Goodkin RS, Greiner K, Nemeroff CB, Miller AH: Paroxetine for the prevention of depression induced by high dose interferone alpha. N Engl J Med 2001, 344:961-966.

46. Lydiatt WM, Denman D, McNeilly DP, Puumula SE, Burke WJ: A randomized placebo- controlled trial of citalopram for the prevention of major depression during treatment for head and neck cancer. Arch Otolaryngol Head Neck Surg 2008, 134:528-535.

47. Massie MJ, Gagnon P, Holland GC: Depression and suicide in patients with cancer. J Pain Symptom Manage 1994, 9:325-340.

48. Van der Feltz-Cornelis CM, Nuyen J, Stoop C, Chan J, Jacobson AM, Katon W, Snoek F, Sartorius N: Effect of interventions for major depressive disorder and significant depressive symptoms in patients with diabetes mellitus: a systematic review and meta-analysis. Gen Hosp Psychiatry 2010, 32:380-395.

49. Price A, Rayner L, Okon-Rocha E, Evans A, Valsraj K, Higginson IJ, Hotopf M: Antidepressants for the treatment of depression in neurological disorders: a systematic review and meta-analysis of randomized controlled trials. J Neurol Neurosurg Psychiatry 2011, 82:914-923.

50. Sherwood Brown E, Vigil L, Khan DA, Liggin JDM, Carmody TJ, John Rush A: A randomized controlled trial of citalopram versus placebo on outpatients with asthma and major depressive disorder: a proof of concept study. Biol Psychiatry 2005, 58:865-870.

51. Baumeister $\mathrm{H}$, Hutter $\mathrm{N}$, Bengel J: Psychological and pharmacological interventions for depression in patients with coronaryartery disease. Cochrane Database Syst Rev 2011 (Issue 9):Art.No.:CD008012. http://onlinelibrary.wiley.com/doi/10.1002/14651858.CD008012.pub3/pdf

52. Baumeister $\mathrm{H}$, Hutter $\mathrm{N}$, Bengel J: Psychological and pharmacological interventions for depression in patients with coronary artery disease. The Cochrane Collaboration 2011

53. Graff $L A$, Walker $J R$, Bernstein $C N$ : Depression and anxiety in inflammatory bowel disease: a review of comorbidity and management. Inflammatory Bowel Disease 2009, 15:1105-1118.

54. Clink HM: Mianserin and blood dyscrasias. Br J Clin Pharmacol 1983, 15(Suppl. 2):291-293.

55. Henry NL, Rae JM, Li L, Azzouz F, Skaar TC, Desta Z, Sikora MJ, Philips S, Nguyen AT, Storniolo AM, Hayes DF, Flockhart DA: Stearns V; Consortium on Breast Cancer Pharmacogenomics Investigators: Association between CYP2D6 genotype and tamoxifen-induced hot flashes in a prospective cohort. Breast Cancer Res Treat 2009, 117:571-575.

56. Desmarais JE, Looper KJ: Interactions between tamoxifen and antidepressants via cytochrome P450 2D6. J Clin Psychiatry 2009, 70:1688-1697.

doi:10.1186/1471-244X-13-140

Cite this article as: Laoutidis and Mathiak: Antidepressants in the treatment of depression/depressive symptoms in cancer patients: a systematic review and meta-analysis. BMC Psychiatry 2013 13:140.

\section{Submit your next manuscript to BioMed Central and take full advantage of:}

- Convenient online submission

- Thorough peer review

- No space constraints or color figure charges

- Immediate publication on acceptance

- Inclusion in PubMed, CAS, Scopus and Google Scholar

- Research which is freely available for redistribution

Submit your manuscript at www.biomedcentral.com/submit
Ciomed Central 